Article

\title{
Functionalization and Evaluation of Inorganic Adsorbents for the Removal of Cadmium in Wastewater
}

\author{
Ana Lucía Campaña ${ }^{1}$ D , Amaimen Guillén ${ }^{1,2}$, Ricardo Rivas ${ }^{3}$, Veronica Akle ${ }^{2}$, Juan C. Cruz ${ }^{4}$ (D) \\ and Johann F. Osma 1,*iD
}

1 Department of Electrical and Electronic Engineering, Universidad de Los Andes, Bogotá 111711, Colombia; al.campana10@uniandes.edu.co (A.L.C.); aa.guillon@uniandes.edu.co (A.G.)

2 Laboratory of Neuroscience and Circadian Rhythms, School of Medicine, Universidad de Los Andes, Bogotá 111711, Colombia; v.akle@uniandes.edu.co

3 Department of Chemistry, Science Faculty, Universidad de Los Andes, Bogotá 111711, Colombia; re.rivas@uniandes.edu.co

4 Department of Biomedical Engineering, Universidad de Los Andes, Bogotá 111711, Colombia; jc.cruz@uniandes.edu.co

* Correspondence: jf.osma43@uniandes.edu.co; Tel.: +57-1-339-4949

check for updates

Citation: Campaña, A.L.; Guillén, A.; Rivas, R.; Akle, V.; Cruz, J.C.; Osma, J.F. Functionalization and Evaluation of Inorganic Adsorbents for the Removal of Cadmium in Wastewater. Molecules 2021, 26, 4150. https:// doi.org/10.3390/molecules26144150

Academic Editor: Frank Alexis

Received: 9 June 2021

Accepted: 3 July 2021

Published: 8 July 2021

Publisher's Note: MDPI stays neutral with regard to jurisdictional claims in published maps and institutional affiliations.

Copyright: (c) 2021 by the authors. Licensee MDPI, Basel, Switzerland This article is an open access article distributed under the terms and conditions of the Creative Commons Attribution (CC BY) license (https:// creativecommons.org/licenses/by/ $4.0 /)$.

\begin{abstract}
This study presents the feasibility of using various functionalized substrates, $\mathrm{Fe}_{3} \mathrm{O}_{4}$ nanoparticles (NPs) and $\mathrm{Al}_{2} \mathrm{O}_{3}$ spheres, for the removal of $\mathrm{Cd}$ from aqueous solution. To improve the materials' affinity to $\mathrm{Cd}$, we explored four different surface modifications, namely (3-Aminopropyl) triethoxysilane (APTES), L-Cysteine (Cys) and 3-(triethoxysilyl) propylsuccinic anhydride (CAS). Particles were characterized by FTIR, FIB-SEM and DLS and studied for their ability to remove metal ions. Modified NPs with APTES proved to be effective for $\mathrm{Cd}$ removal with efficiencies of up to $94 \%$, and retention ratios up to $0.49 \mathrm{mg}$ of $\mathrm{Cd}$ per $\mathrm{g}$ of NPs. Batch adsorption experiments investigated the influence of $\mathrm{pH}$, contact time, and adsorbent dose on $\mathrm{Cd}$ adsorption. Additionally, the recyclability of the adsorbent and its potential phytotoxicity and animal toxicity effects were explored. The Langmuir, Freundlich, pseudo-first-order and pseudo-second-order models were applied to describe the behavior of the $\mathrm{Cd}$ adsorption processes. The adsorption and desorption results showed that $\mathrm{Fe}_{3} \mathrm{O}_{4}$ NPs modified with APTES are promising low-cost platforms with low phytotoxicity for highly efficient heavy metal removal in wastewater.
\end{abstract}

Keywords: wastewater; cadmium; magnetite nanoparticles; alumina; functionalization

\section{Introduction}

Cadmium $(\mathrm{Cd})$ is a relatively scarce heavy metal found in the earth's crust and the inevitable product of the extraction of zinc, lead, and copper. In the environment, $\mathrm{Cd}$ only exists in one oxidation state $(+2)$, dissolving easily in polluted waters with low $\mathrm{pH}$ levels and typically transported to freshwaters used for human consumption [1,2]. One of the main sources of Cd contamination is poorly treated domestic, industrial and agricultural wastewater which usually contains high concentrations of heavy metals [1]. The concentrations of this element in wastewater have been reported to vary from 0 to $1000 \mathrm{mg} / \mathrm{L}$, depending on the discharge source [3]. This is a major environmental and health concern because the established maximum level of this pollutant according to the U.S. Environmental Protection Agency (US EPA) is $0.005 \mathrm{mg} / \mathrm{L}$ for drinking water [4] and, according to the International Agency for Research on Cancer (IARC), Cd is linked to kidney damage, chronic renal failure, osteoporosis, and cancer, mainly due to its marked tendency for bioaccumulation $[1,5,6]$. Thus, $\mathrm{Cd}$ traces must be effectively removed before the discharge of wastewater into the environment $[7,8]$.

Several Cd removal methods have been studied and implemented on an industrial scale, including chemical precipitation [3], solvent extraction [9,10], flocculation [11], electrochemical treatment [12], membrane filtration [13] and adsorption. Among them, 
adsorption-based processes are considered simple, cost-effective, and sustainable alternatives for heavy metal removal. For this, some of the preferred adsorbents include different variations of activated carbon [14], carbon nanotubes [15,16], various nanoparticles [17-20] and agricultural waste by-products such as rice husk, fly ash [21], sunflower waste [22,23] and chitosan $[24,25]$. The attractiveness of these materials as adsorbents stems from the fact that they exhibit a high surface area, high adsorption capacity, mechanical stability, and ease of recovery. Despite their potential, many of these substrates show insufficient superficial active sites and their specificity towards the effective removal of metal ions is highly limited. To overcome this issue, recent nanotechnology approaches have provided novel surface modification routes to introduce functional groups that show a higher affinity for $\mathrm{Cd}$ chelation and consequently, are capable of considerably increasing the sorption capacity of these materials [26-28]. The Hosain et al. study on magnetic nanoparticles cross-linked succinic anhydride reported a maximum removal efficiency of $\mathrm{Cd}$ from wastewater samples of 57.6\% [29] and Chen et al. [30] a removal of 96\% using functionalized $\mathrm{Fe}_{3} \mathrm{O}_{4}$ nanoparticles. For nanomaterials based on alumina $\left(\mathrm{Al}_{2} \mathrm{O}_{3}\right)$, the maximum removal efficiencies reported are between $31 \%$ and $99 \%$ [31,32]. These, however, rarely include the recovery studies and toxicity analysis to determine the viability of using the related components on a larger scale.

Despite the ample number of emerging treatments, much work is still needed to ensure effective water treatment processes that are also economically feasible and sustainable in the long run. Hence, the purpose of this work is to evaluate the efficiency of nanocomposite materials as practical treatment options. In this work, two inorganic substrates, $\mathrm{Al}_{2} \mathrm{O}_{3}$ spheres and $\mathrm{Fe}_{3} \mathrm{O}_{4}$ nanoparticles (NPs) with four different surfaces modifications are proposed for $\mathrm{Cd}$ adsorption. Here, we evaluated the effect of $\mathrm{pH}$, contact time, and substrate dose on Cd removal. Additionally, one of the adsorbents was analyzed for recyclability, as well as for the environmental repercussions of their use.

\section{Results}

The study of the removal of $\mathrm{Cd}$ from water was carried out using two distinct inorganic surfaces, commercial $\mathrm{Al}_{2} \mathrm{O}_{3}$ spheres of 600-800 $\mu$ m diameter and produced $\mathrm{Fe}_{3} \mathrm{O}_{4}$ NPs. These substrates were selected as they both can be easily retrieved from liquid environments which makes them ideal materials for large scale heavy metal treatment processes. Additionally, different surface functionalizations were prepared to evaluate their effect on the $\mathrm{Cd}$ removal efficiency. The substrates were functionalized by silanization with two different organo-silane molecules, APTES and CAS, then further functionalized with L-Cysteine (Cys). The final evaluated substrates were the original materials and the adsorbents modified with CAS, CAS@Cys, APTES, and APTES@Cys. The adsorbent with the best recovery and removal results was then further evaluated at different $\mathrm{pH}$ values, contact time and adsorbent dose. Two kinetic and isotherm models of this adsorbent were also fitted to the obtained data.

\subsection{Characteristics of the Adsorbents}

\subsubsection{Dynamic Light Scattering (DLS) of $\mathrm{Fe}_{3} \mathrm{O}_{4} \mathrm{NPs}$}

The size distribution of the synthesized $\mathrm{Fe}_{3} \mathrm{O}_{4} \mathrm{NPs}$ was measured using DLS. Figure 1 shows that the particle size distribution of bare $\mathrm{Fe}_{3} \mathrm{O}_{4} \mathrm{NPs}$ solution presented two main peaks centered at $39.4 \pm 9.1 \mathrm{~nm}(8.9 \%)$ and $323.6 \pm 107.2 \mathrm{~nm}(91.1 \%)$. A polydispersity index (PDI) of 0.329 indicated that the synthesized particles exhibited uniform sizes. Most of the NPs exhibited a size somewhat larger than expected for this synthesis method, which was attributed to particle agglomeration processes. This can also be inferred from the standard deviation of largest peak that was significantly wider than expected for a monodisperse sample. 


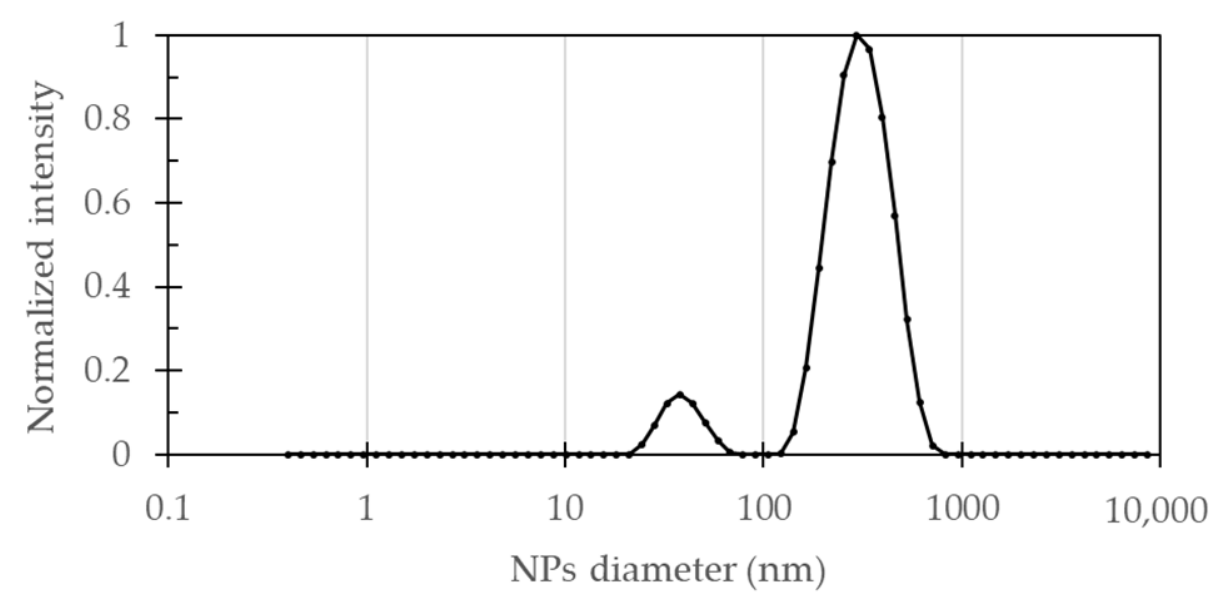

Figure 1. DLS result of particle size distribution for bare $\mathrm{Fe}_{3} \mathrm{O}_{4}$ NPs nanoparticles in aqueous suspension. The first peak from left to right is centered at $39.4 \pm 9.1 \mathrm{~nm}(8.9 \%)$ while the second one is at $323.6 \pm 107.2 \mathrm{~nm}(91.1 \%)$.

\subsubsection{Focused Ion Beam-Scanning Electron Microscopy (FIB-SEM) with EDX Analysis}

The morphology and size of the adsorbents before and after $\mathrm{Cd}$ removal experiments were studied via FIB-SEM. Figure 2 shows the corresponding micrographs for the adsorbents prior and after modification with (3-Aminopropyl) triethoxysilane (APTES), and after $\mathrm{Cd}$ removal. The micrographs for the bare $\mathrm{Fe}_{3} \mathrm{O}_{4}$ NPs (Figure 2a,b) show a typical spherical and monodispersed morphology, however, unfunctionalized particles appear to have higher agglomeration in contrast with the APTES-modified NPs (Figure 2a-c). The mean size of bare $\mathrm{Fe}_{3} \mathrm{O}_{4} \mathrm{NPs}$ is approximately $10-30 \mathrm{~nm}$, which agrees with one of the peaks found with the DLS analysis. No apparent change in the NPs diameter was observed after Cd removal experiments.

(a)

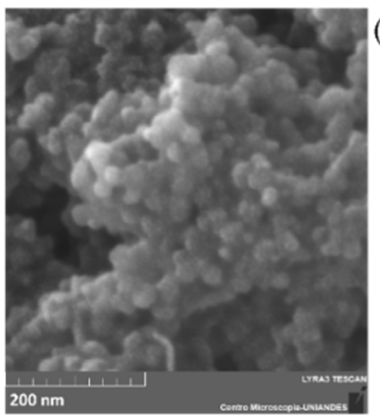

(d)

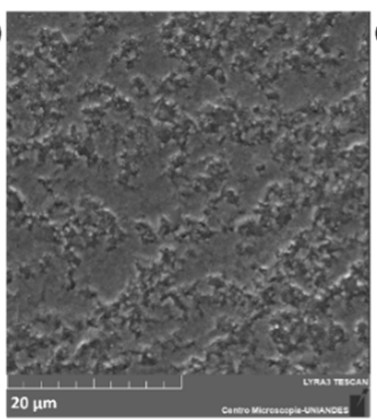

(b)
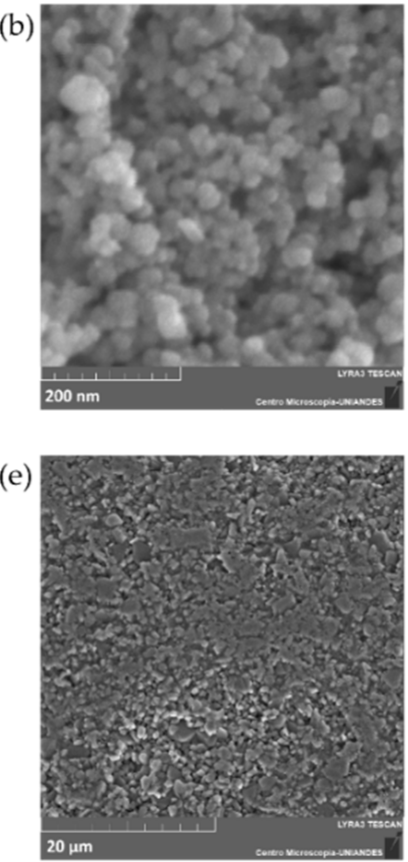

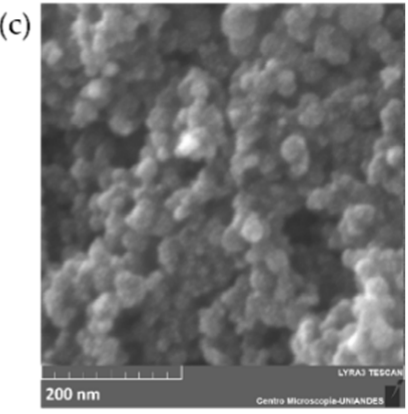

(f)

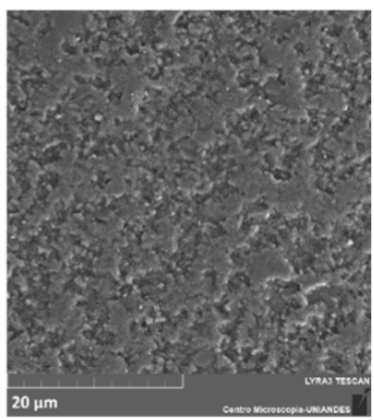

Figure 2. SEM images of (a) $\mathrm{Fe}_{3} \mathrm{O}_{4} \mathrm{NPs}$, (b) $\mathrm{Fe}_{3} \mathrm{O}_{4}$ NPs @APTES, (c) $\mathrm{Fe}_{3} \mathrm{O}_{4}$ NPs after Cd removal, (d) $\mathrm{Al}_{2} \mathrm{O}_{3}$ spheres, (e) $\mathrm{Al}_{2} \mathrm{O}_{3} @$ @PTES, and (f) $\mathrm{Al}_{2} \mathrm{O}_{3}$ spheres after $\mathrm{Cd}$ removal. 
Figure $2 \mathrm{~d}-\mathrm{f}$ show a rough surface for the $600-800 \mu \mathrm{m} \mathrm{Al}_{2} \mathrm{O}_{3}$ spheres, which is usually observed for high superficial area and superficially porous materials [33,34]. However, a closer inspection of the surface revealed a highly dense material with low porosity, which most likely indicates that the spheres have a much lower surface-active area for functionalization than the NPs counterparts.

The EDX results shown in Figure 3 confirmed the modification with the organo-silanes, APTES and 3-(triethoxysilyl) propylsuccinic anhydride (CAS) on $\mathrm{Fe}_{3} \mathrm{O}_{4} \mathrm{NPs}$ and $\mathrm{Al}_{2} \mathrm{O}_{3}$ spheres. The presence of silicon ( $\mathrm{Si}$ ) in the spectrum after modification strongly indicates a correct functionalization with the organosilane molecules; however, in the case of $\mathrm{Al}_{2} \mathrm{O}_{3}$ spheres, the presence of $\mathrm{Si}$ is frequently related to initial traces of silicon on the material. However, in the control sample there was no evidence of a Si peak, which is why the $\mathrm{Si}$ in the modified material can be related to surface functionalization, not the original sample composition.

(a)

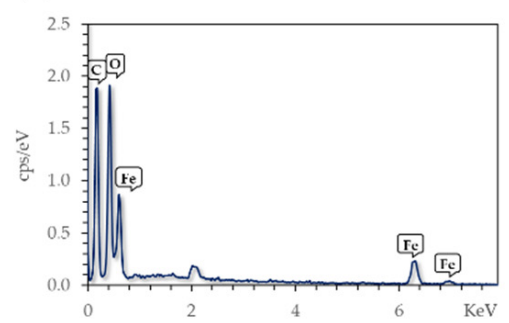

(d)

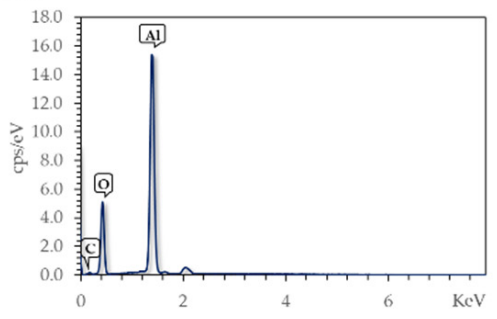

(b)

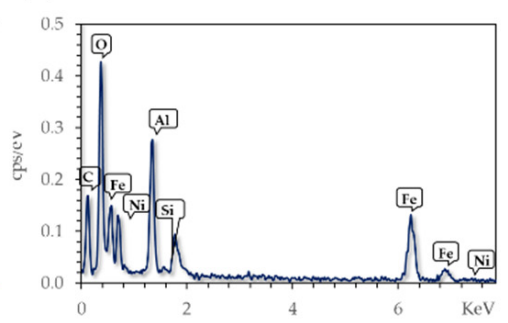

(e)

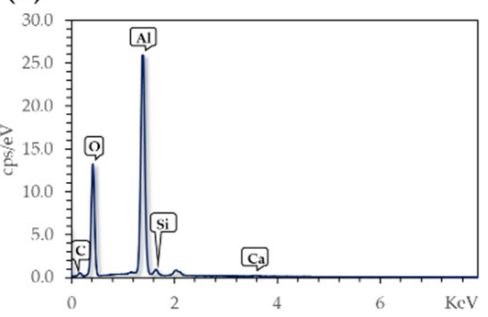

(c)

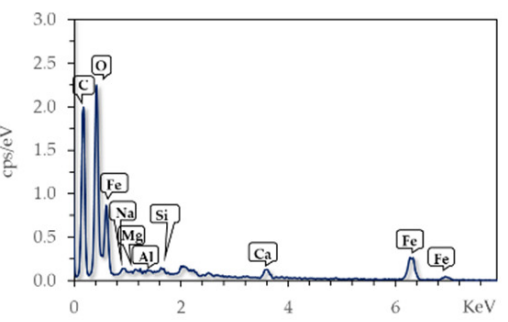

(f)

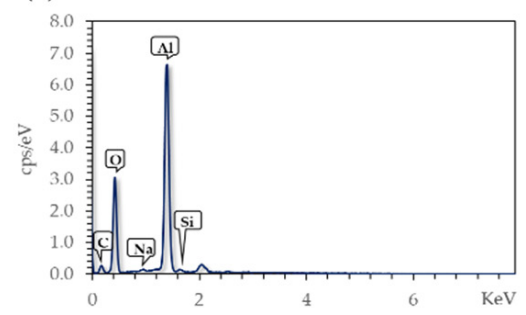

Figure 3. EDX results of (a) $\mathrm{Fe}_{3} \mathrm{O}_{4} \mathrm{NPs}$, (b) $\mathrm{Fe}_{3} \mathrm{O}_{4}$ NPs @APTES, (c) $\mathrm{Fe}_{3} \mathrm{O}_{4}$ NPs @APTES after Cd removal, (d) $\mathrm{Al}_{2} \mathrm{O}_{3}$ spheres, (e) $\mathrm{Al}_{2} \mathrm{O}_{3}$ spheres @APTES, and (f) $\mathrm{Al}_{2} \mathrm{O}_{3}$ spheres @APTES after Cd removal.

Samples after Cd treatment were also evaluated via EDX (Figure 3c,f). There were no traces of $\mathrm{Cd}$ in any of the studied substrates. The initial concentration of $\mathrm{Cd}$ for the adsorption experiments was $0.1 \mathrm{mg} / \mathrm{L}$, and consequently, the adsorbed amount by the materials was expected to be lower than $1 \%$ on weight basis. This poses a difficulty in the detection of adsorbed $\mathrm{Cd}$, as the resolution of this method is inadequate for this limit.

\subsubsection{Fourier Transform Infrared Spectroscopy (FTIR) Analysis}

FTIR analysis was performed to corroborate the effective surface modifications for the $\mathrm{Al}_{2} \mathrm{O}_{3}$ spheres and $\mathrm{Fe}_{3} \mathrm{O}_{4}$ NPs. Figure $4 a$, b show the IR spectra and chemical structure of the pure molecules used for the surface modification, while Figure $4 c$, d show the IR spectra of the substrates before and after their conjugation on the adsorbents.

The strong peaks near 1100 and $800 \mathrm{~cm}^{-1}$ found in pure APTES and CAS spectra (Figure $4 \mathrm{a}$ ), are attributed to $\mathrm{Si}-\mathrm{O}-\mathrm{Si}$ and $\mathrm{Si}-\mathrm{O}$ stretching vibrations, respectively [35,36]. These bands were also found in the modified $\mathrm{Fe}_{3} \mathrm{O}_{4}$ NPs as shown in Figure $4 \mathrm{~d}$ and provided further evidence of the correct silanization of the surface. Peaks around $1800 \mathrm{~cm}^{-1}$ in pure CAS (Figure 4a) are due to $\mathrm{C}=\mathrm{O}$ stretching of the anhydride group, that can also be seen on $\mathrm{Fe}_{3} \mathrm{O}_{4} \mathrm{NPs}$ modified with CAS in Figure 4d. After the second modification with Cys to form the $\mathrm{Fe}_{3} \mathrm{O}_{4} \mathrm{NPs} @$ CAS@Cys nanocompounds, these bands disappear when the anhydride group opens to covalently bind the Cys. In contrast, none of the modifications of 
$\mathrm{Al}_{2} \mathrm{O}_{3}$ spheres with the organo-silanes was confirmed by this method as the corresponding bands were absent in the spectra (Figure 4c).

(a)

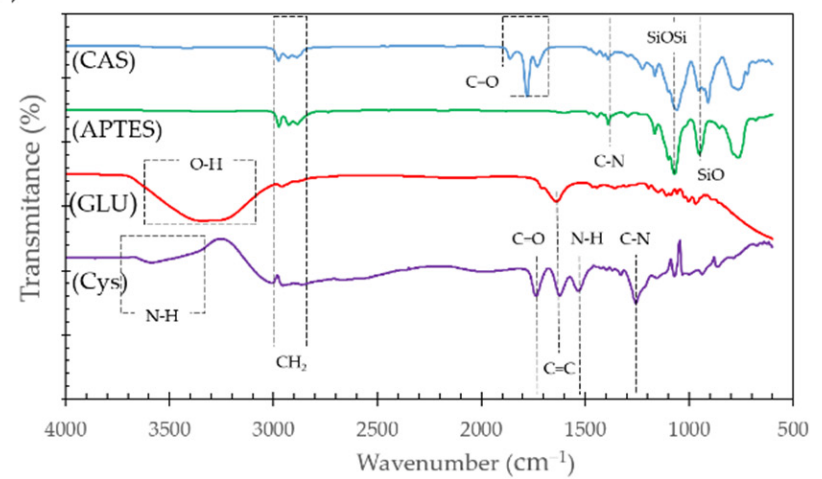

(c)

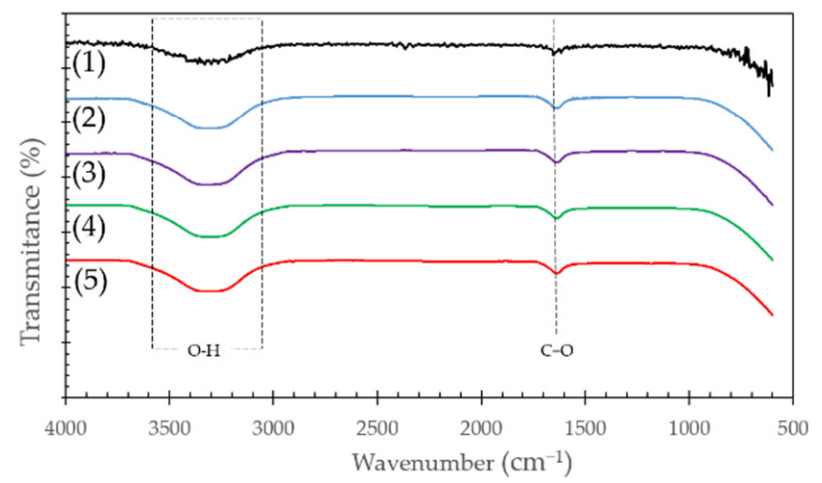

(b)<smiles>CCO[Si](CCCC1CC(=O)OC1=O)(OCC)OCC</smiles><smiles>O=CCCCC=O</smiles><smiles>N[C@@H](CS)C(=O)O</smiles>

(GLU)

(d)

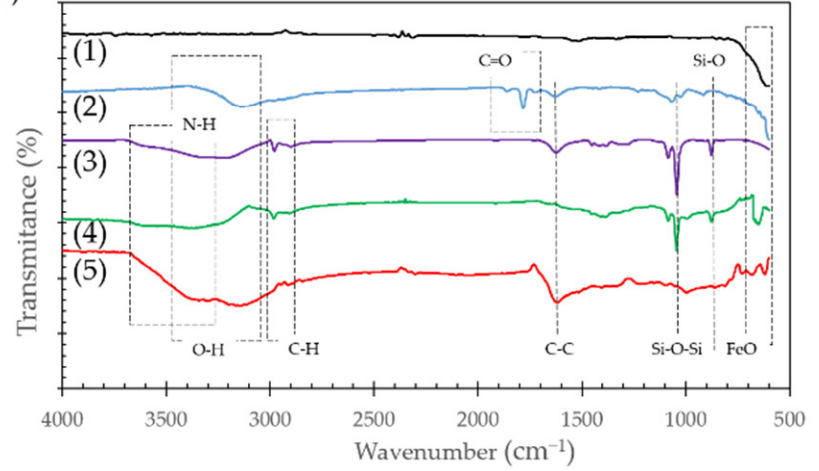

Figure 4. FTIR spectra (a) and chemical structure (b) of pure CAS, APTES, GLU and Cys. Additionally, FTIR spectra of (c) $\mathrm{Al}_{2} \mathrm{O}_{3}$ spheres and (d) $\mathrm{Fe}_{3} \mathrm{O}_{4}$ NPs. Each one functionalized with (2) CAS, (3) CASCys, (4) APTES and (5) APTES@GLU@Cys. The spectra of bare adsorbents were added for comparison (1).

A broad peak at around $3500-3000 \mathrm{~cm}^{-1}$ can be related to the $\mathrm{O}-\mathrm{H}$ stretching vibration of the carboxyl group and the strong peaks close to $1620 \mathrm{~cm}^{-1}$ to the strong stretching vibration of $\mathrm{C}=\mathrm{C}$, which can also be found in the modified $\mathrm{Fe}_{3} \mathrm{O}_{4}$ NPs (Figure $4 \mathrm{~d}$ ). Of particular interest is the N-H stretching vibration present in APTES and Cys because it can be associated with the free amine groups of both molecules that have been thought to improve $\mathrm{Cd}$ adsorption. Figure $4 \mathrm{~d}$ exhibited a broad absorption band at around $3200-3600 \mathrm{~cm}^{-1}$, which can also be attributed to the free amine groups after conjugation of both molecules on the $\mathrm{Fe}_{3} \mathrm{O}_{4}$ NPs.

Bare $\mathrm{Fe}_{3} \mathrm{O}_{4}$ NPs in Figure $4 \mathrm{~d}$ exhibited adsorption bands at around $700-600 \mathrm{~cm}^{-1}$, which can be attributed to the stretching vibration of the Fe-O bond of iron oxide [37]. The study of $\mathrm{Al}_{2} \mathrm{O}_{3}$ spheres with FTIR failed to show immobilization of any compound and only showed the $\mathrm{C}=\mathrm{O}$ and $\mathrm{O}=\mathrm{H}$ peaks related to surface oxidation, element traces or environmental $\mathrm{H}_{2} \mathrm{O}$ (Figure $4 \mathrm{c}$ ).

Weak bands at 3000-2700 $\mathrm{cm}^{-1}$ in the modified $\mathrm{Fe}_{3} \mathrm{O}_{4}$ NPs spectra (Figure 4d) were related to the $\mathrm{C}-\mathrm{H}$ stretching vibration that can be also found in pure APTES, CAS and Cys (Figure $4 \mathrm{a}$ ). In the particular case of Cys, this band could be also related to the stretching vibration of the S-H group [38].

\subsection{Effect of Surface Functionalization on Cd Removal}

The removal of $\mathrm{Cd}$ using the two inorganic surfaces with and without surface modifications was carried out in batch experiments at a $0.1 \mathrm{mg} / \mathrm{L}$ concentration of $\mathrm{Cd}$ in water. This experiment was intended to evaluate whether a particular surface modification 
showed a higher affinity for $\mathrm{Cd}$ in aqueous solution. The adsorption of the heavy metals is highly related to the properties of the adsorbent and the type of $\mathrm{Cd}$ ions species present in solution [18]. Figure 5a shows the removal efficiency of Cd by each adsorbent. The removal efficiencies of the control substrates without any surface modifications were below 51\% in all cases. The best results for both functionalized and bare substrates were obtained for $\mathrm{Fe}_{3} \mathrm{O}_{4}$ NPs. The highest percentage of $\mathrm{Cd}$ removal of all the adsorbents was attained with $\mathrm{Fe}_{3} \mathrm{O}_{4}$ NPs functionalized with APTES, where $\mathrm{Cd}$ removal from aqueous solutions reached $94 \%$.
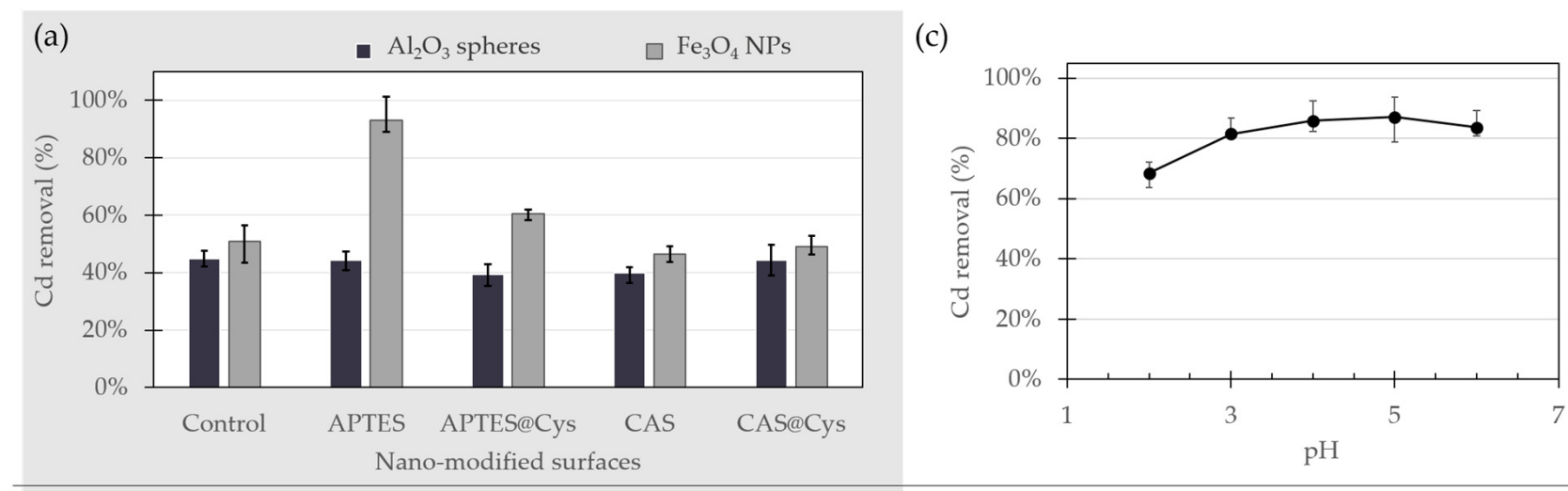

(b)
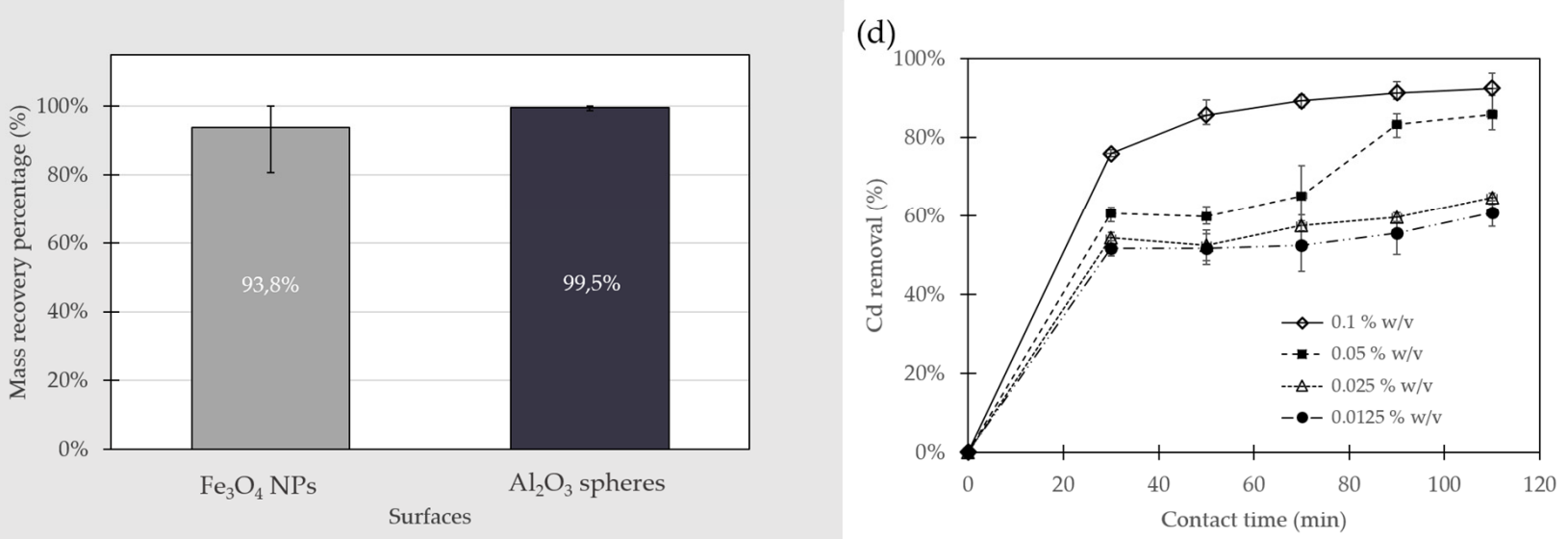

Figure 5. (a) Percentage of $\mathrm{Cd}$ removal in aqueous solution for $\mathrm{Al}_{2} \mathrm{O}_{3}$ spheres and $\mathrm{Fe}_{3} \mathrm{O}_{4} \mathrm{NPs}$. Removal efficiency ( $\mathrm{R} \%$ ) was studied before and after surface modifications. (b) Adsorbent mass recovery after the removal assays. (c) Percentage of $\mathrm{Cd}$ removal at $\mathrm{pH}$ values in the range of 2.0-6.0 for $\mathrm{Fe}_{3} \mathrm{O}_{4}$ NPs @APTES. (d) Removal efficiency of $\mathrm{Cd}$ on $\mathrm{Fe}_{3} \mathrm{O}_{4}$ NPs @APTES as a function of contact time. Initial metal concentration of $0.1 \mathrm{mg} / \mathrm{L} ; \mathrm{pH} 5.0$ and adsorbent dose in the range of $0.0125-0.1 \%(w / v)$.

$\mathrm{Al}_{2} \mathrm{O}_{3}$ spheres presented low removal efficiencies even after surface modification (Figure 5a). Bare $\mathrm{Al}_{2} \mathrm{O}_{3}$ spheres showed a $\mathrm{Cd}$ removal percentage of $44.7 \%$, which was higher than any of the modified alumina spheres studied as evidenced by removal efficiencies as low as $39.4 \%$. These results were expected, considering that the FTIR results showed no evidence of surface functionalization for $\mathrm{Al}_{2} \mathrm{O}_{3}$. Moreover, this substrate exhibited a highly irregular surface with low porosity and therefore lower superficial area for adsorption. As reported elsewhere, a nanoparticulated version of $\mathrm{Al}_{2} \mathrm{O}_{3}$ has already shown significant potential as an adsorbent for heavy metal removal from water $[39,40]$, however, they are different in size, superficial area, and available active sites compared with the bulk counterpart used here. There are alternative possibilities for improving the functionalization by pre-activating the surface via hydrolyzation, spraying of the modifying agents, or by thermal treatments [41], however, these methodologies were not considered in this work. 
There is marked interest from the scientific community in this magnetic nanoadsorbent for its unique properties, such as large surface area, low toxicity, high biocompatibility and simple separation and recovery from aqueous solutions with the aid of relatively low magnetic fields $[18,36]$. Unmodified $\mathrm{Fe}_{3} \mathrm{O}_{4} \mathrm{NPs}$ showed a $\mathrm{Cd}$ removal efficiency of $50.8 \%$ (Figure 5a) similar to the $57.6 \%$ reported by Hosain et al. [29] for $\mathrm{Fe}_{3} \mathrm{O}_{4} \mathrm{NPs}$ coated with nanochitosan but lower than the $96 \%$ reported by Chen et al. [30], using functionalized $\mathrm{Fe}_{3} \mathrm{O}_{4}$ nanoparticles with APTES. This suggests that their intrinsic ability for $\mathrm{Cd}$ removal could also be improved by increasing the affinity of the surface for the $\mathrm{Cd}$ ions. The already active surface of $\mathrm{Fe}_{3} \mathrm{O}_{4}$ NPs displays a significant number of hydroxyl groups, thereby it allows an effective functionalization with the organo-silanes to eventually improve the NPs' capacity to bind $\mathrm{Cd}$. In general, the $\mathrm{Cd}$ binding capacity of modified $\mathrm{Fe}_{3} \mathrm{O}_{4} \mathrm{NPs}$ largely depends on the type of surface modification. The $\mathrm{Fe}_{3} \mathrm{O}_{4} \mathrm{NPs}$ modified with APTES showed an improved $\mathrm{Cd}$ removal percentage, which is in contrast with CAS functionalization where a reduction was observed. The highest efficiency was 93.2\% in $\sim 18 \mathrm{~h}$ of exposure for $\mathrm{Fe}_{3} \mathrm{O}_{4}$ NPs @APTES, which is clearly superior to that achieved with other functionalized NPs.

\subsection{Substrate Recovery from Water}

An ideal adsorbent should not only have a high adsorption capacity but induce reduced environmental impact. Here, we studied whether the adsorbents can be recovered from the treatment solutions after $\mathrm{Cd}$ removal to assess their potential reusability. We also wanted to evaluate if discharging back the recovered adsorbents to the environment might lead to possible environmental impacts. The $\mathrm{Fe}_{3} \mathrm{O}_{4} \mathrm{NPs}$ were recovered by magnetic means while the $\mathrm{Al}_{2} \mathrm{O}_{3}$ spheres were filtered out from the solutions with a $500 \mu \mathrm{m}$ pore size metallic filter. Figure $5 \mathrm{~b}$ shows the mass percentage recovered after $\mathrm{Cd}$ removal tests for $\mathrm{Fe}_{3} \mathrm{O}_{4} \mathrm{NPs}$ and $\mathrm{Al}_{2} \mathrm{O}_{3}$ spheres. Even though $\mathrm{Al}_{2} \mathrm{O}_{3}$ had the lowest capacity for $\mathrm{Cd}$ removal, they were effectively recovered from the solutions after their use. $\mathrm{Al}_{2} \mathrm{O}_{3}$ spheres showed the highest mass recovery of $99.5 \%$ in comparison with the $93.8 \%$ of the magnetic nanoparticles. However, considering the $\mathrm{Cd}$ removal results, $\mathrm{Fe}_{3} \mathrm{O}_{4} \mathrm{NPs} @ \mathrm{APTES}$ was selected as the best material for $\mathrm{Cd}$ removal and was further used for additional tests and characterizations. The possible environmental effect of the approximately $6.2 \%$ of the non-recovered adsorbent was also evaluated.

\subsection{Effect of Solution $\mathrm{pH}$ on $\mathrm{Cd}$ Removal}

The removal of $\mathrm{Cd}$ using $\mathrm{Fe}_{3} \mathrm{O}_{4}$ NPs @APTES was studied for $\mathrm{pH}$ values in the range of 2.0-6.0 in experiments that lasted for $18 \mathrm{~h}$. The type of ionized Cd species in solution is one of the most relevant parameters for effective adsorption. As reported by Jain et al. [23], $\mathrm{Cd}^{2+}$ is predominant in deionized water if the $\mathrm{pH}$ of the aqueous solution is lower than 7.0, and a subsequent increase in $\mathrm{pH}$ causes its precipitation as $\mathrm{Cd}(\mathrm{OH})_{2}$ [42].

The $\mathrm{Cd}$ removal efficiencies of the adsorbent at different $\mathrm{pH}$ values are shown in Figure 5c. Lower $\mathrm{Cd}$ removal percentages for $\mathrm{Fe}_{3} \mathrm{O}_{4} \mathrm{NPs} @$ APTES were obtained at low $\mathrm{pH}$ values, which suggests that $\mathrm{H}^{+}$ions in the aqueous solution are most likely bound to some of binding sites available on the material. Our results show a trend where cadmium removal increased as a function of $\mathrm{pH}$. An increase in $\mathrm{pH}$ slightly improved $\mathrm{Cd}$ adsorption from $68.5 \%$ to $87.2 \%$ and reached a maximum at $\mathrm{pH} 5.0$. For this reason, all the remaining experiments were carried out at this $\mathrm{pH}$ value. The decreased $\mathrm{Cd}$ capture above $\mathrm{pH} 6.0$ could be related to precipitation $\mathrm{Cd}$ ions as $\mathrm{Cd}(\mathrm{OH})_{2}$.

\subsection{Effect of Contact Time and Adsorbent Dose on Cd Removal}

Adsorption time is important for understanding the adsorption mechanisms of the adsorbate. The effect of time on adsorption of $\mathrm{Cd}$ by $\mathrm{Fe}_{3} \mathrm{O}_{4} \mathrm{NPs} @$ APTES is presented in Figure $5 \mathrm{~d}$. The percentage of $\mathrm{Cd}$ removal was evaluated for $110 \mathrm{~min}$ with four different doses of adsorbent, ranging from $0.0125 \%(w / v)$ to $0.1 \%(w / v)$. The removal of Cd increased rapidly in the first $30 \mathrm{~min}$ of exposure. The difference in concentration of $\mathrm{Cd}$ ions in the solution and the nanoparticles resulted in the fast diffusion of the element to the surface of 
the absorbent. This was followed by a regime of decreased adsorption for all the different studied doses of $\mathrm{Fe}_{3} \mathrm{O}_{4}$ NPs @APTES. For this adsorbent, a further increase in contact time had no significant effect on Cd removal after $90 \mathrm{~min}$. The already occupied active sites in the adsorbent surface are charged positively by $\mathrm{Cd}$ and repel the free ions in the solution, thereby decreasing the adsorption rate. Cadmium removal at equilibrium increased as the adsorbent dose increased, most likely due to exposure to a higher superficial area with available binding sites for $\mathrm{Cd}$ ions $[18,22]$. The time evolution of adsorption was similar for almost all studied doses with the exception of $0.05 \%(w / v)$. Cd removal reached maxima in the range of $60.7 \%$ to $92.5 \%$ after $110 \mathrm{~min}$, corresponding to removal ratios ranging from 0.49 to $0.09 \mathrm{mg}$ of $\mathrm{Cd}$ per $\mathrm{g}$ of NPs, respectively.

\subsection{Adsorption Isotherms}

To investigate further the adsorption behavior of $\mathrm{Fe}_{3} \mathrm{O}_{4}$ NPs @APTES, we fitted the adsorption data to the widely used Langmuir and Freundlich models.

The Langmuir model is frequently used to describe the deposition of a complete monolayer of the metal on the surface of the material via adsorption processes. This model assumes that the $\mathrm{Cd}$ ions are adsorbed by forming a homogeneous monolayer on the active sites in the surfaces of the adsorbent and there are no interactions between the adsorbed ions [32]. This is described by Equation (1) [43,44]:

$$
\frac{1}{q_{e}}=\left(\frac{1}{k_{L} q_{m} C_{e}}\right)+\frac{1}{q_{m}}
$$

where $C_{e}\left(\mathrm{mg} \mathrm{g}^{-1}\right)$ is the concentration of adsorbate in the solution at equilibrium; $q_{e}\left(\mathrm{mg} \mathrm{g}^{-1}\right)$ is the adsorption capacity at equilibrium of the adsorbent surface; $k_{L}\left(\mathrm{~L} \mathrm{mg}^{-1}\right)$ is the Langmuir isotherm constant and $q_{m}\left(\mathrm{mg} \mathrm{g}^{-1}\right)$ is the monolayer capacity of the adsorbent. According to this equation, the plot of $1 / q_{e}$ vs. $1 / C_{e}$ should be a straight line with slope $1 / q_{m}$ and intercept $1 /\left(k_{L} q_{m}\right)$. The Langmuir isotherm can be also expressed in terms of the dimensionless factor $R_{L}$, which is defined by Equation (2) [45]:

$$
R_{L}=\left(\frac{1}{1+k_{L} \times C_{o}}\right)
$$

The dominant adsorption mechanism can be deduced from the $R_{L}$ values, it can be either unfavorable $\left(R_{L}>1\right)$, linear $\left(R_{L}=1\right)$, favorable $\left(0<R_{L}<1\right)$ or irreversible $\left(R_{L}=0\right)$. $\mathrm{Fe}_{3} \mathrm{O}_{4}$ NPs adsorption yield a $R_{L}<1$, which indicates a favorable adsorption. The data fitted a linear adsorption process (Table 1 ) as evidenced with a correlation coefficient of 0.929 for $\mathrm{Fe}_{3} \mathrm{O}_{4} \mathrm{NPs} @$ APTES. The Langmuir model fits relatively well the adsorption data for $\mathrm{Fe}_{3} \mathrm{O}_{4} \mathrm{NPs}$, which suggests that the assumption of a monolayer deposition might be correct for this adsorbent (Figure 6a). The $q_{m}$ value of $\mathrm{Fe}_{3} \mathrm{O}_{4}$ NPs @APTES is $1334.94 \mathrm{mg} / \mathrm{g}$, which is reasonable compared with others reported previously by Javaheri, F. et al. [46] of $884.906 \mathrm{mg} / \mathrm{g}$ for $\mathrm{Fe}_{3} \mathrm{O}_{4} @ \mathrm{SiO}_{2} @ \mathrm{~m}-\mathrm{SiO}_{2}-\mathrm{NH}_{2}$ and $769.2 \mathrm{mg} / \mathrm{g}$ for nano zerovalent iron presented by Boparai et al. [47].

Table 1. Langmuir and Freundlich models parameters recovered for $\mathrm{Fe}_{3} \mathrm{O}_{4}$ NPs @APTES.

\begin{tabular}{cccc}
\hline \multicolumn{2}{c}{ Langmuir Model } & \multicolumn{2}{c}{ Freundlich Model } \\
\hline Isotherm Parameters & Values & Isotherm Parameters & Values \\
\hline$q_{m}$ & 1334.96 & $\mathrm{n}$ & 1.214 \\
$K_{L}$ & 7.002 & $K_{f}$ & 36.979 \\
$R_{L}$ & 0.588 & - & - \\
$R^{2}$ & 0.929 & $R^{2}$ & 0.873 \\
\hline
\end{tabular}

The Freundlich linear model is not restricted to a monolayer formation and includes the heterogeneous interaction between the material surface and the metal ion. This model 
indicates that the $\mathrm{Cd}$ ions are adsorbed on an uneven surface not only forming monolayers in the active sites but also uneven multilayers. Therefore, the energy distribution for the surface-active sites of the adsorbent is uneven in contrast with the Langmuir model [48]. The expression for Freundlich model is given by Equation (3) [35,45]:

$$
\log \left(q_{e}\right)=\log \left(k_{f}\right)+\frac{1}{n} \log \left(C_{e}\right)
$$

where $k_{f}\left(L g^{-1}\right)$ is the Freundlich constant and $n\left(g L^{-1}\right)$ is the constant exponent that describes the intensity of the adsorption process [35]. According to this equation, the plot of $\log \left(q_{e}\right)$ vs. $\log C_{e}$ should be a straight line with slope $1 / n$ and intercept $K_{f}$.

(a)

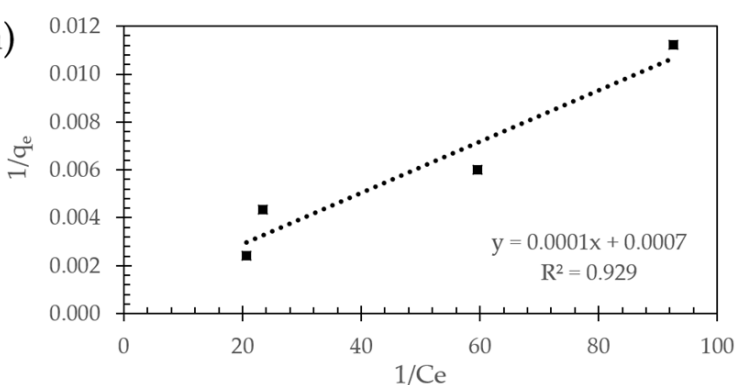

(c)

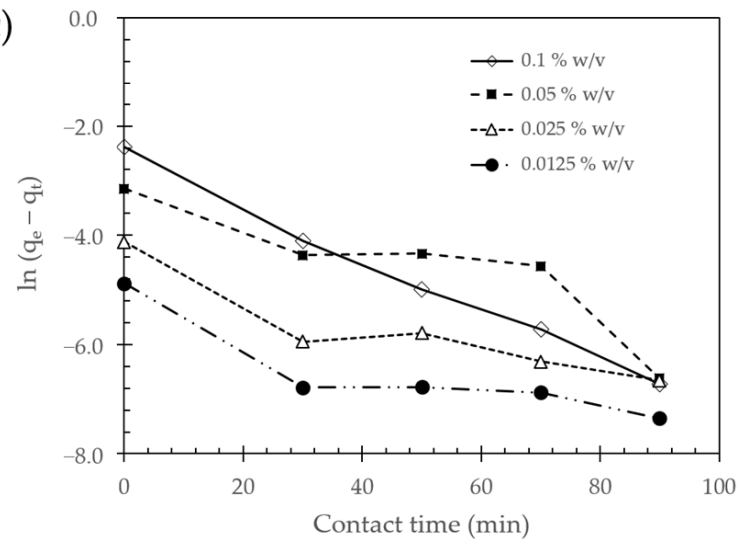

(b)

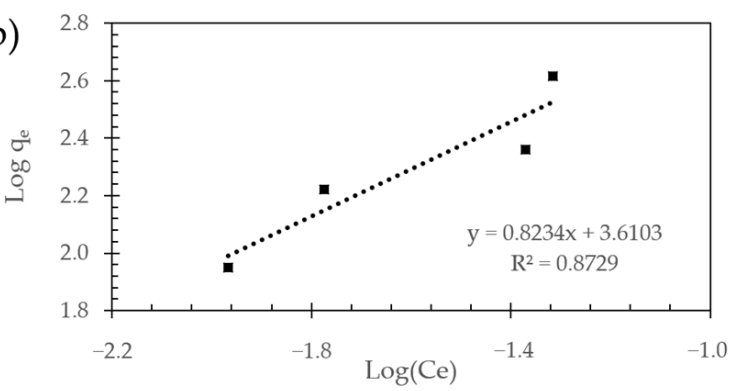

(d)

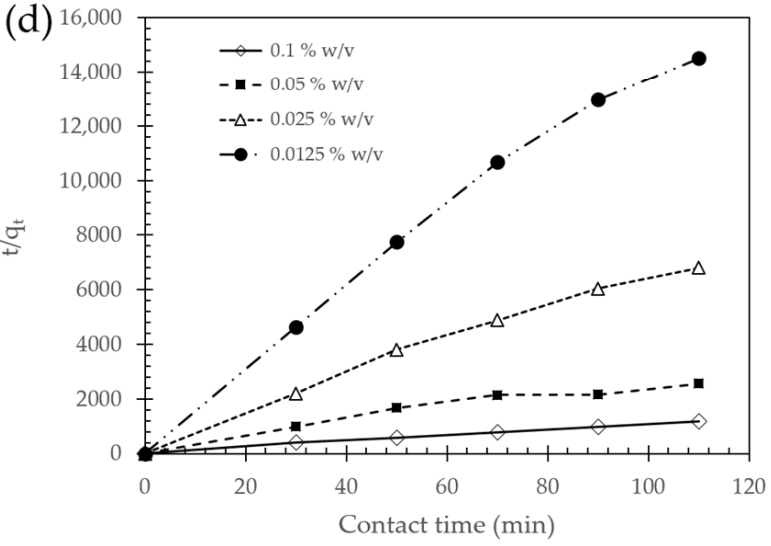

Figure 6. Linearized (a) Langmuir and (b) Freundlich adsorption isotherms of $\mathrm{Fe}_{3} \mathrm{O}_{4}$ NPs @APTES at $18{ }^{\circ} \mathrm{C}$; (c) pseudofirst-order (PFO) and (d) pseudo-second-order (PSO) kinetic plots for Cd adsorption with $\mathrm{Fe}_{3} \mathrm{O}_{4}$ NPs @APTES.

The deviation from linearity for the Freundlich model can be estimated from $\mathrm{n}$ values. In this regard, this parameter can be either unfavorable $(n<1)$, linear $(n=1)$, favorable $(n>1)$ or irreversible $(n=0) . \mathrm{Fe}_{3} \mathrm{O}_{4}$ NPs yield a $n>1$, which could be associated with a favorable reaction [45]. The correlation coefficient was 0.873 for $\mathrm{Fe}_{3} \mathrm{O}_{4}$ NPs @APTES. Consequently, in comparison with the Langmuir model, the Freundlich one appears to describe the adsorption process less accurately for $\mathrm{Fe}_{3} \mathrm{O}_{4}$ NPs (Figure 6b).

Despite the fact that the Langmuir correlation coefficient $\left(R^{2}=0.929\right)$ is higher than the Freundlich model $\left(R^{2}=0.873\right)$, they are relatively low compared with similar reports in literature of $0.9973,0.9950,0.99$ or 0.98 [32,48]. This is usually an indication that none of the constructed curves describes with high accuracy the adsorption behavior and there could be a more complex mechanism that governs the adsorption of $\mathrm{Cd}$ on this substrate. Other adsorption models such as the Dubinin-Radeshkevich may be able to provide a better mechanistic description of the process but the study of such a mechanism is beyond the scope of the present contribution. 


\subsection{Kinetic Studies}

To describe the adsorption kinetics, the experimental data was fitted to both the pseudo-first-order (PFO) model and the pseudo-second-order (PSO) model.

The PFO model is described by the following differential equation (Equation (4)) [49-51]:

$$
\frac{d q_{t}}{d t}=k_{1}\left(q_{e}-q_{t}\right)
$$

where $q_{t}\left(\mathrm{mg} \mathrm{g}^{-1}\right)$ and $q_{e}\left(\mathrm{mg} \mathrm{g}^{-1}\right)$ are the metal ions adsorbed at time $t(\min )$ and at equilibrium, respectively, while $k_{1}\left(\mathrm{~min}^{-1}\right)$ is the PFO rate constant. After integration between $t=0$ to $t=t$ and $q=0$ to $q=q$ the obtained expression is (Equation (5)):

$$
\ln \left(q_{e}-q_{t}\right)=\ln q_{e}-k_{1} t
$$

The adsorption kinetics (Figure 6c and Table 2) were fitted to the PFO model by plotting $\ln \left(q_{e}-q_{t}\right)$ vs. $t$. The calculated parameters showed that the data failed to follow the PFO model for the studied surfaces and concentrations. The mean $R^{2}$ was 0.852 for $\mathrm{Fe}_{3} \mathrm{O}_{4}$ NPs @APTES, which indicates a substantial deviation from linearity. Such deviation becomes quite apparent at $10 \mathrm{~min}$, which is most likely due to a fast initial uptake of metal ions [52].

Table 2. Experimental and PFO parameters for $\mathrm{Fe}_{3} \mathrm{O}_{4}$ NPs @APTES at four different substrate concentrations $\%(w / v)$. [ $C_{o}=0.1 \mathrm{mg} / \mathrm{L}$; mixing rate: $\left.200 \mathrm{rpm} ; \mathrm{T}=18{ }^{\circ} \mathrm{C} ; \mathrm{pH}=5.0\right]$.

\begin{tabular}{ccccc}
\hline \multirow{2}{*}{ Parameters } & \multicolumn{4}{c}{$\mathrm{Fe}_{3} \mathrm{O}_{\mathbf{4}}$ NPs @APTEs Concentrations \% (w/v) } \\
\cline { 2 - 5 } & $\mathbf{0 . 0 1 2 5 \%}$ & $\mathbf{0 . 0 2 5 \%}$ & $\mathbf{0 . 0 5 \%}$ & $\mathbf{0 . 1} \%$ \\
\hline$q_{e}$ calculated & 0.0046 & 0.0107 & 0.0469 & 0.0806 \\
$K_{1}$ calculated & 0.0240 & 0.0256 & 0.0323 & 0.0472 \\
$q_{e}$ experimental & 0.0076 & 0.0162 & 0.0429 & 0.0925 \\
$R^{2}$ & 0.7719 & 0.8370 & 0.8043 & 0.9936 \\
\hline
\end{tabular}

The PSO model is described by the following differential equation (Equation (6)) [20,51]:

$$
\frac{d q_{t}}{d t}=k_{2}\left(q_{e}-q_{t}\right)^{2}
$$

where $q_{t}\left(\mathrm{mg} \mathrm{g}^{-1}\right)$ and $q_{e}\left(\mathrm{mg} \mathrm{g}^{-1}\right)$ are the metal ions adsorbed at time $t(\mathrm{~min})$ and at equilibrium, respectively, while $k_{2}\left(\mathrm{~g} \mathrm{mg}^{-1} \mathrm{~min}^{-1}\right)$ is the PSO rate constant. After integration between $t=0$ to $t=t$ and $q=0$ to $q=q$ the obtained expression is (Equation (7)):

$$
\frac{t}{q_{t}}=\frac{1}{K_{2} q_{e}^{2}}-\frac{t}{q_{e}}
$$

The parameters of the kinetic model were calculated by plotting $t / q_{t}$ vs. $t$. As shown in Table 3 and Figure $6 \mathrm{~d}$, the values of the calculated $q_{e}$ are similar to those found experimentally. The mean correlation coefficient $\left(R^{2}\right)$ for $\mathrm{Fe}_{3} \mathrm{O}_{4}$ NPs @APTES was 0.976. This corroborated a much better fitting of the PSO model compared with the PFO one.

The concentrations used for this experiment were increased from $0.0125 \%(w / v)$ to $0.1 \%(w / v)$, which was the one selected to evaluate the other parameters, such as $\mathrm{pH}$, reusability and surface functionalization. The lower concentration of adsorbent possibly explains why the PSO model showed a better data fit than the PFO [49]. Several reports have shown that by increasing the adsorbent's initial concentration, the correlation of the experimental data with the PSO kinetics model decreases while it decreases for the PFO model [49]. The PSO model assumes that the rate of adsorption of metal ions on the surface 
is directly proportional to the available binding sites on the material. Consequently, for $\mathrm{Fe}_{3} \mathrm{O}_{4}$ NPs @APTEs, it is very likely that the adsorption process is highly dependent on the amount of $\mathrm{Cd}$ in direct contact with the surface of the substrates and the number of available active sites. In this work, the calculated and experimental values for $q_{e}$ in both PFO and PSO models are close to $0.007 \mathrm{mg} / \mathrm{g}$, which is particularly small compared with those reported previously of $8.852 \mathrm{mg} / \mathrm{g}$ [48] and $9.13 \mathrm{mg} / \mathrm{g}$ [29]. This result could be explained by two of the initial conditions of the experiment. First, the low initial concentration of the stock Cd solution $(0.1 \mathrm{mg} / \mathrm{L})$, which is in some cases three orders of magnitude lower than those reported in other studies $[29,30,48]$. Second, the studied concentrations of adsorbent. Although our substrate had a removal efficiency of $94 \%$, the maximum evaluated concentration was $0.1 \mathrm{mg} / \mathrm{L}$ and the ratio of initial free metal ions and available adsorption sites was relatively low for the studied doses of adsorbent. Subsequently, we suggest that we were most likely operating below the complete adsorption capacity of the material, and in therefore the values for the $q_{e}$ could change in higher initial cadmium concentrations.

Table 3. Experimental and PSO parameters for $\mathrm{Fe}_{3} \mathrm{O}_{4}$ NPs @APTES at four different substrate concentrations $\%(w / v)$. [ $C_{o}=0.1 \mathrm{mg} / \mathrm{L} ;$ mixing rate: $\left.200 \mathrm{rpm} ; \mathrm{T}=18{ }^{\circ} \mathrm{C} ; \mathrm{pH}=5.0\right]$.

\begin{tabular}{ccccc}
\hline \multirow{2}{*}{ Parameters } & \multicolumn{3}{c}{$\mathrm{Fe}_{3} \mathrm{O}_{4}$ NPs @APTEs Concentrations \% $(w / v)$} \\
\cline { 2 - 4 } & $\mathbf{0 . 0 1 2 5 \%}$ & $\mathbf{0 . 0 2 5 \%}$ & $\mathbf{0 . 0 5 \%}$ & $\mathbf{0 . 1 \%}$ \\
\hline$q_{e}$ calculated & 0.0074 & 0.0160 & 0.0439 & 0.0942 \\
$K_{2}$ calculated & 31.8227 & 12.5918 & 1.9662 & 2.9968 \\
$q_{e}$ experimental & 0.0076 & 0.0162 & 0.0429 & 0.0925 \\
$R^{2}$ & 0.9877 & 0.9865 & 0.9336 & 0.9962 \\
\hline
\end{tabular}

\subsection{Life Cycle and Desorption Studies}

The life cycle capacity of the adsorbent was estimated by conducting four cycles of $\mathrm{Cd}$ removal. The $\mathrm{Cd}$ removal efficiencies of the modified substrate per cycle without any desorption or recovery process in between cycles are shown in Figure 7a. The adsorbent showed a linear decreasing capacity for $\mathrm{Cd}$ adsorption after each cycle. The limit of reusability was established as an accumulated reduction in the adsorption capacity of $50 \%$. For $\mathrm{Fe}_{3} \mathrm{O}_{4}$ NPs @APTES, the adsorption capacity was never reached for the conducted experiments; however, by following the linear tendency, it is expected to be close after the fifth cycle.

(a)

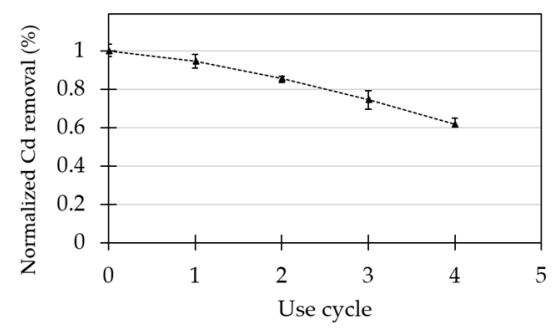

(b)

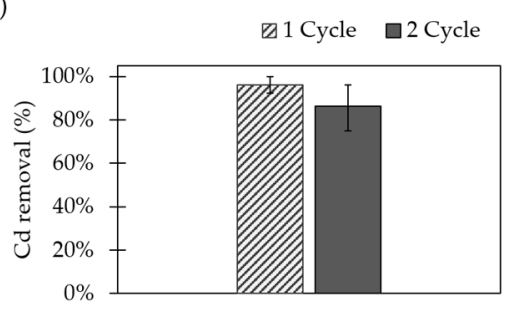

(c)

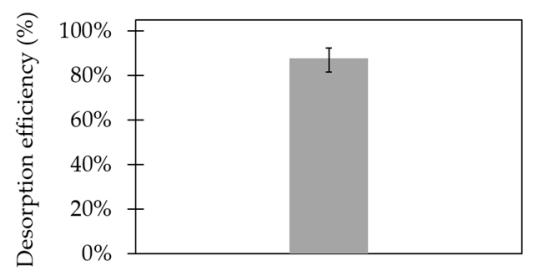

Figure 7. Percentage of $\mathrm{Cd}$ removal per cycle of $\mathrm{Fe}_{3} \mathrm{O}_{4}$ NPs @APTES (a) without desorption between cycles; (b) after desorption of surfaces by $0.1 \%(v / v) \mathrm{HCl}$ solutions as regenerating agent; and (c) desorption efficiency after regeneration treatment.

The ability to regenerate the surface is key for the economic and sustainable application of the developed adsorbents. For this reason, desorption studies were carried out with the aid of a $0.1 \%(v / v) \mathrm{HCl}$ solution as the regenerating agent. The reusability of adsorbents was studied by evaluating the percentage of $\mathrm{Cd}$ removal before and after desorption 
(Figure 7b). Moreover, the desorption efficiency was calculated for $\mathrm{Fe}_{3} \mathrm{O}_{4}$ NPs @APTES (Figure 7c).

As reported by Katarina et al., in an acid medium such as $\mathrm{HCl}$ solution, $\mathrm{Cd}$ ions bound to chelating functional groups in the material are replaced by $\mathrm{H}^{+}$[18]. $\mathrm{For} \mathrm{Fe}_{3} \mathrm{O}_{4}$ NPs @APTES, the attained desorption efficiency was $87.6 \pm 5.4 \%$. Furthermore, on the second use cycle, the $\mathrm{Cd}$ adsorption percentage for $\mathrm{Fe}_{3} \mathrm{O}_{4}$ NPs @APTES decreased from $96.1 \pm 3.9 \%$ to $86.4 \pm 6.8 \%$. In general, this indicates that this nanocompound shows good reusability for cyclical operation at the reported concentrations.

\subsection{Environmental Repercussion}

\subsubsection{Phytotoxicity}

A simple, rapid, sensitive, and low-cost method to evaluate NP toxicity is through the study of seed germination and root elongation of plant seeds [53]. Figure 8 shows the impact on seed germination, root and shoot growth of NPs at six different concentrations in the range of 0.1 to $1000 \mu \mathrm{g} / \mathrm{mL}$. Seed germination was recorded after the fourth and seventh day of exposure. The results were then used to calculate the percentage of germination for each treatment. Seed germinations appeared largely unaffected by the NPs as evidenced by values above $60 \%$ for all evaluated concentrations (Figure $8 \mathrm{a}$ ). Although the multiple comparison tests seemed to show no significant differences between the evaluated groups (with $p=0.198$ ), Levene's test showed $p=0.007$, thereby suggesting that a least one of the treatments was different, which was corroborated by applying a Tukey test where the $\mathrm{Fe}_{3} \mathrm{O}_{4}$ NPs @APTES@GLU@Cys treatment was found to be statistically different from the others. The treatment that seemed to affect germination the most was $\mathrm{Fe}_{3} \mathrm{O}_{4}$ NPs@APTES@GLU@Cys with a value 6.6\% below the average (i.e., about $87 \%$ ). This was followed by $\mathrm{Fe}_{3} \mathrm{O}_{4} \mathrm{NPs}$ with a value $2.4 \%$ below the average. In contrast, the remaining treatments showed germination values above the average. $\mathrm{Fe}_{3} \mathrm{O}_{4} \mathrm{NPs} @ \mathrm{CAS}$ was indeed $1.7 \%$ above the average, and finally, $\mathrm{Fe}_{3} \mathrm{O}_{4}$ NPs @APTES was $7.35 \%$ above the average. Concentrations between 0.01 and $10 \mu \mathrm{g} / \mathrm{mL}$ showed no significant differences in germination, but those at $100 \mu \mathrm{g} / \mathrm{mL}$ and above led to germination changes in a concentration dependent manner.

The root and shoot elongation (Figure $8 \mathrm{~b}, \mathrm{c}$ ) were affected differently by each adsorbent. Changes in root elongation were observed in the roots of each seed. Multiple comparisons between treatments for the longest root showed a $p=0.04$, indicating that at least one of them was statistically different. Here, the group of seeds treated with unmodified $\mathrm{Fe}_{3} \mathrm{O}_{4}$ NPs showed the lowest elongations in its main root with up to $0.39 \mathrm{~cm}$ below the average length (i.e., $2.43 \mathrm{~cm}$ ). Even though for NPs modified with APTES, the root and shoot elongations were not significantly inhibited, the effect of the treatment was still unclear. A slight inhibition of shoot and root growth was observed for $\mathrm{Fe}_{3} \mathrm{O}_{4} \mathrm{NPs} @ \mathrm{CAS}$ at $10 \mu \mathrm{g} / \mathrm{mL}$ but surprisingly, not at the highest evaluated concentration.

Overall, $\mathrm{Fe}_{3} \mathrm{O}_{4} \mathrm{NPs}$ showed no observable phytotoxicity except for the highest concentration, i.e., $1000 \mu \mathrm{g} / \mathrm{mL}$. If NPs are to be used for wastewater treatment at a concentration of $0.1 \%(w / v)$, the approximate concentration of lost NPs in the environment, according to the reported WR\%, would be approximately $62 \mu \mathrm{g} / \mathrm{mL}$. At this concentration, no evident phytotoxicity effects on germination, root length, or shoot elongation were observable, which suggests a potentially low environmental impact. However, large-scale experiments with long-term exposure to realistic concentrations of $\mathrm{Fe}_{3} \mathrm{O}_{4} \mathrm{NPs}$ are still needed to come to a definitive conclusion [54].

\subsubsection{NPs Toxicity in Zebrafish Embryos}

Survival in zebrafish embryos was determined by observation of activity and movement, heart rate, and changes in blood circulation [55]. Survival was evaluated from 3 to $96 \mathrm{hpf}$ (Figure 9a) showing statistically significant differences $\left(p=3 \times 10^{-12}\right)$. Even though the effect of the exposure to the NC was concentration-dependent, the concentration of 25 and $50 \mu \mathrm{g} / \mathrm{mL}$, showed minimal mortality rates and no evidence of malformations, 
while exposure to $100 \mu \mathrm{g} / \mathrm{mL}$ was highly lethal. According to the OECD guide, this result suggests that concentrations of 25 and $50 \mu \mathrm{g} / \mathrm{mL}$ present in the water, should not be considered harmful [56]. During the treatment, accumulation of NPs was observed in the chorion, which became more evident as the concentration increased (Figure 9b). However, this experiment was insufficient to determine if the observed accumulation led to significant changes in the normal development of the embryos or if hatching was inhibited by blockage of the chorionase activity [57], the presence of acids in the medium [58], and/or changes in hypoxia [59].
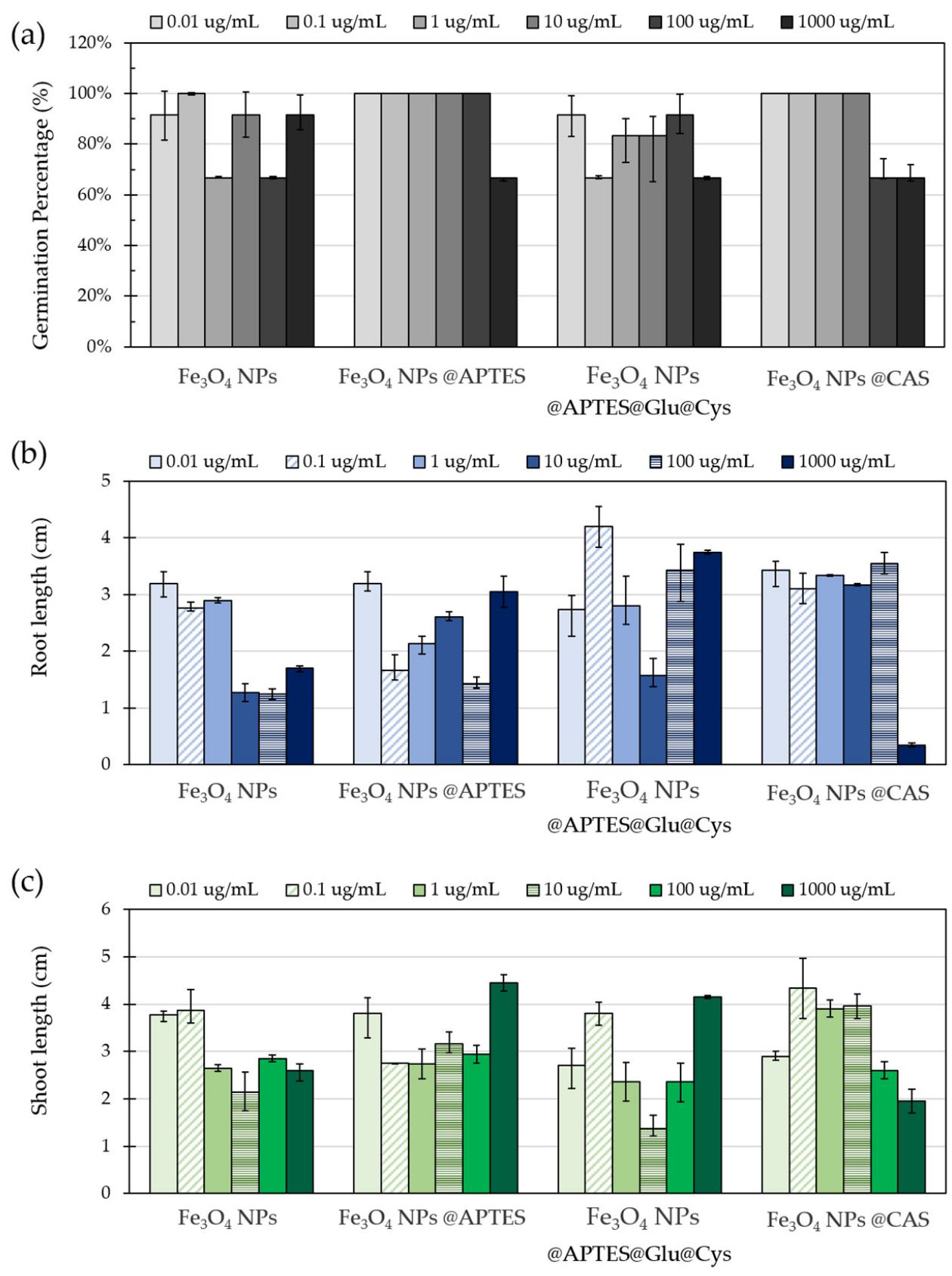

Figure 8. (a) Germination percentage, (b) root and (c) shoot length of ryegrass seed after 6 days of exposure to bare $\mathrm{Fe}_{3} \mathrm{O}_{4} \mathrm{NPs}$ and $\mathrm{Fe}_{3} \mathrm{O}_{4}$ NPs functionalized with APTES, APTES@Glu@Cys and CAS. 
(a)

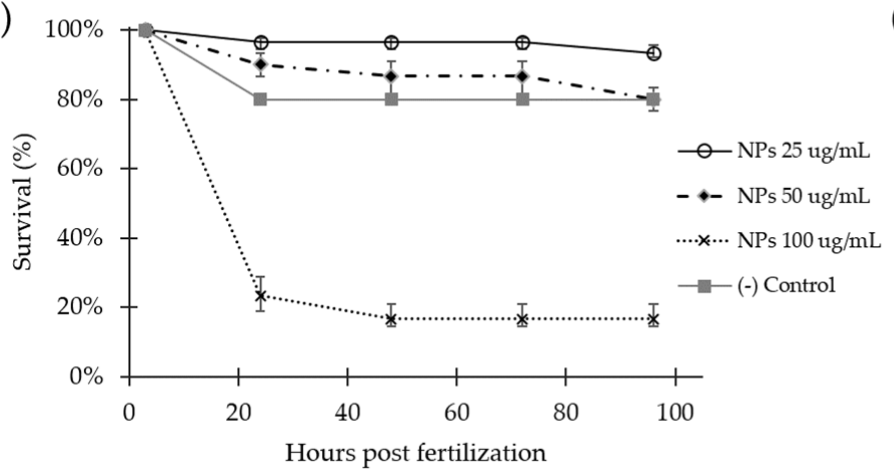

(b)

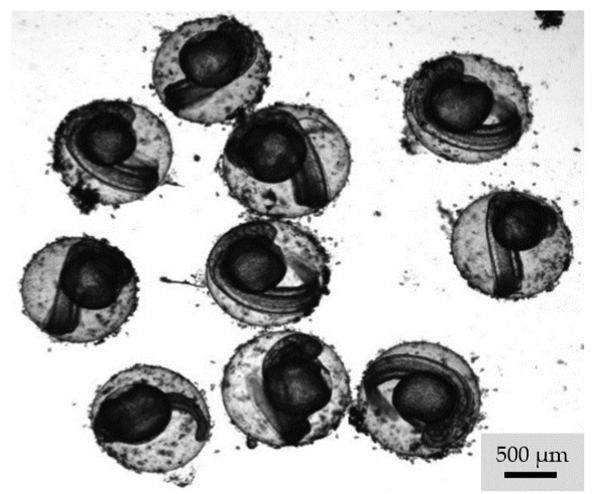

Figure 9. (a) Survival rate for embryos exposed to different concentrations of $\mathrm{Fe}_{3} \mathrm{O}_{4}$ NPs @APTES $(25,50 \mathrm{and} 100 \mu \mathrm{g} / \mathrm{mL})$ compared with the control group. Data are showed as percentage of survival $(n=30$ embryos for each concentration and a control that was normalized to the highest survival well). (b) Stereoscope image of $48 \mathrm{hpf}$ embryos exposed to $\mathrm{Fe}_{3} \mathrm{O}_{4} \mathrm{NPs}$ @APTES at $25 \mu \mathrm{g} / \mathrm{mL}$.

\section{Materials and Methods}

\subsection{Materials}

Iron (III) chloride hexahydrate $(97 \%)\left(\mathrm{FeCl}_{3} \cdot 6 \mathrm{H}_{2} \mathrm{O}\right)$, tetramethylammonium hydroxide (TMAH) (25\%), (3-Aminopropyl) triethoxysilane (APTES) (98\%) and L-Cysteine (Cys) (97\%) were purchased from Sigma-Aldrich (St. Louis, MO, USA). Iron (II) chloride tetrahydrate $(98 \%)\left(\mathrm{FeCl}_{2} \cdot 4 \mathrm{H}_{2} \mathrm{O}\right)$, glutaraldehyde (25\%) (GLU), Cd standard solution $1000 \mathrm{mg} / \mathrm{L}$ and sodium hydroxide $(\mathrm{NaOH})$ (98\%) were obtained from PanReac AppliChem (Barcelona, Spain). Additionally, 3-(triethoxysilyl) propylsuccinic anhydride (CAS) (95\%) was purchased from Shanghai Kayi Chemical Co. (Shanghai, China). Commercial aluminum oxide spheres (Alumina) between $600-800 \mu \mathrm{m}$ of diameter were acquired from Torrecid (L'Alcora, Castellón, Spain).

\subsection{Manufacture and Functionalization of Surfaces}

\subsubsection{Synthesis of $\mathrm{Fe}_{3} \mathrm{O}_{4}$ NPs}

Nanoparticles were synthetized by co-precipitation method, using $2 \mathrm{M} \mathrm{FeCl}_{3} \cdot 6 \mathrm{H}_{2} \mathrm{O}$ and $1 \mathrm{M} \mathrm{FeCl}_{2} \cdot 4 \mathrm{H}_{2} \mathrm{O}$, diluted in milli-Q water. Solutions were then magnetically stirred and subsequently dripped to a $10 \mathrm{~mL}$ solution $8 \mathrm{M}$ of $\mathrm{NaOH}$ with a syringe pump 78-8110C Programmable Touch Screen (Cole-Parmer, Vernon Hills, IL, USA) at $0.2 \mathrm{~mL} / \mathrm{min}$ of infusing flow rate for $60 \mathrm{~min}$. At the same time, the solution was stirred at $1500 \mathrm{rpm}$ and $90{ }^{\circ} \mathrm{C}$ in the stirring hot plate. The final solution was left to precipitate with the aid of a neodymium magnet for $12 \mathrm{~h}$. The resulting supernatant was discarded, and the precipitate was re-dispersed and washed adding milli-Q water, until pH 7.0 was reached.

\subsubsection{Surface Functionalization of Substrates}

Substrates were functionalized by silanization with two different organo-silane molecules, APTES and CAS. Surface hydrolysis was used to promote silane immobilization by exposing overnight the substrates to a $\mathrm{pH} 11.0$ solution. The solution was prepared using milli-Q water and adding drops of $0.5 \mathrm{M} \mathrm{NaOH}$ until reaching $\mathrm{pH}$ 11.0. For $\mathrm{Fe}_{3} \mathrm{O}_{4}$ NPs silanization, $10 \mathrm{~mL}$ of $0.5 \%(v / v)$ APTES or CAS solution was added to $20 \mathrm{~mL}$ aqueous suspension of $\mathrm{Fe}_{3} \mathrm{O}_{4}$ NPs $0.016 \mathrm{~g} / \mathrm{mL}$ and sonicated for $10 \mathrm{~min}$. Similarly, $2 \mathrm{~g}$ of activated $\mathrm{Al}_{2} \mathrm{O}_{3}$ spheres were dispersed in solutions of APTES or CAS $0.2 \%(v / v)$. All the reactions were carried out for $24 \mathrm{~h}$ at room temperature. Next, the functionalized surfaces were washed several times with abundant milli-Q to remove excess reagents.

Additionally, a second functionalization with L-Cysteine was carried out by following two different functionalization schemes (Figure 10). Previously silanized substrates (with APTES), were first allowed to activate in a solution of GLU 1\% (v/v) for $30 \mathrm{~min}$. This was followed by thoroughly rinsing the substrate with milli-Q water to avoid nonspecific ad- 
sorption of the GLU. Alternatively, substrates silanized with CAS followed a succinylation of the anhydride group with the terminal amine group of Cys. The reaction was conducted under a basic $\mathrm{pH}$ conditions (i.e., pH: 8.0-10.0). Both CAS and APTES@GLU substrates were subsequently reacted with Cys at $0.01 \%(w / v)$ overnight (Figure $10 \mathrm{~b}, \mathrm{c})$. All reactions were carried out at room temperature.

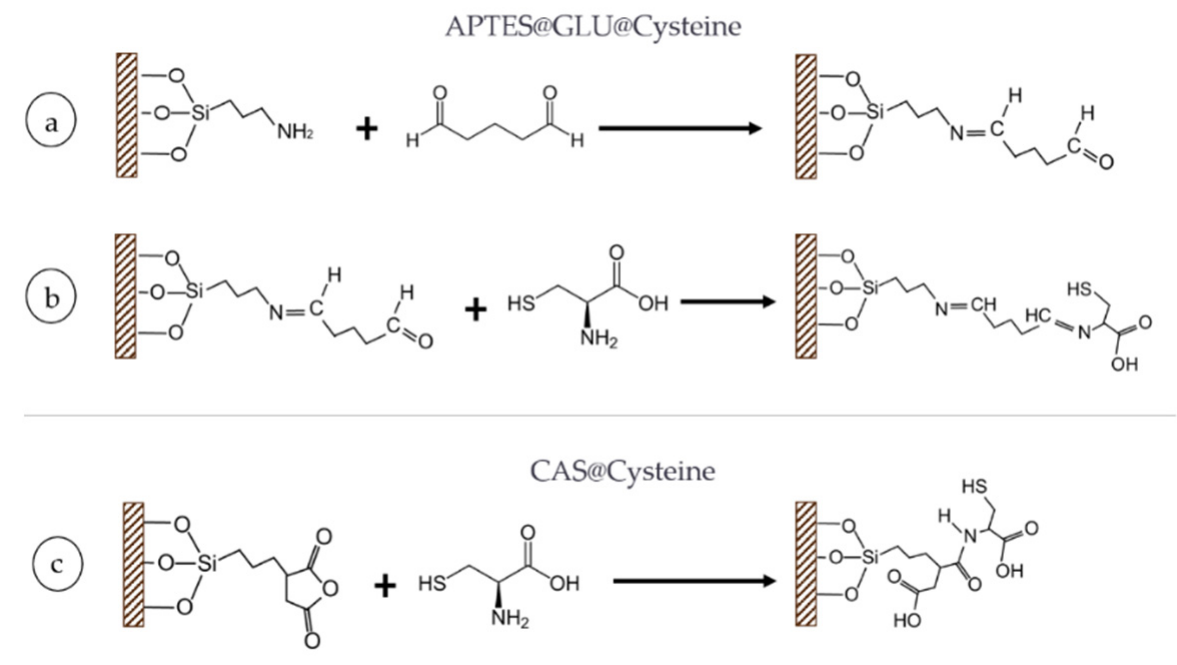

Figure 10. Schematic representation of the surface modifications with L-Cysteine. Substrate modification with (a) first step of APTES followed by Glutaraldehyde, (b) second step of APTES@GLU and then L-Cysteine, and (c) CAS and then L-Cysteine.

\subsection{Adsorbent Characterization}

The hydrodynamic diameter of the synthesized $\mathrm{Fe}_{3} \mathrm{O}_{4} \mathrm{NPs}$ was determined at room temperature by Dynamic Light Scattering (DLS) using a Zetasizer Nano ZS, (Malvern Panalytical, Malvern, Worcestershire, UK). This was accomplished by resuspending the magnetic NPs at $3 \%(w / v)$ in $1 \mathrm{~mL}$ of milli-Q water in the presence of $100 \mu \mathrm{L}$ TMAH. Morphology and composition of both substrates before and after functionalization were studied with focused ion beam-scanning electron microscope (FIB-SEM). For the measurement, the samples were placed on aluminum-coated slices previously covered with carbon tape and then coated by evaporation with a thin film of $\mathrm{Au}$ to improve resolution and signal to noise ratio. Imaging was carried out under vacuum at a beam potency of $10 \mathrm{kV}$ and $5000 \mathrm{X}$ of magnification with a Jeol Lyra 3 (TESCAN, Brno, Czech Republic). The surface modification of $\mathrm{Fe}_{3} \mathrm{O}_{4} \mathrm{NPs}$, and $\mathrm{Al}_{2} \mathrm{O}_{3}$ spheres with APTES, CAS, Glutaraldehyde and L-Cysteine were also verified via Fourier transform infrared spectroscopy (FTIR) using a Bruker Alpha II FTIR Eco-ATR (Bruker, Ettlinglen, Germany). Spectra were collected in the range of $4000-500 \mathrm{~cm}^{-1}$ with a spectral resolution of $2 \mathrm{~cm}^{-1}$ at room temperature.

\subsection{Cd Removal Studies}

Adsorption experiments were carried out in batches by maintaining $10 \mathrm{mg}$ of substrate per $10 \mathrm{~mL}$ of Cd solution $(0.1 \%(w / v)$ overnight $(\sim 18 \mathrm{~h})$ at room temperature) and $200 \mathrm{rpm}$ agitation in a VWR Standard orbital shaker (Avantor, Radnor, PA, USA). Control samples of the original $\mathrm{Cd}$ solution were taken prior to $\mathrm{Cd}$ removal assays and all measurements were conducted in triplicate. After the removal experiments, $\mathrm{Fe}_{3} \mathrm{O}_{4} \mathrm{NPs}$ were recovered using a strong neodymium magnet. $\mathrm{Al}_{2} \mathrm{O}_{3}$ spheres were separated and recovered from the solutions with a $500 \mu \mathrm{m}$ pore size metallic filter.

A stock solution of $0.1 \mathrm{mg} / \mathrm{L}$ of Cd was prepared from a $1000 \mathrm{mg} / \mathrm{L} \mathrm{Cd}$ standard solution with milli-Q water. The $\mathrm{Cd}$ concentration in the solutions was measured via 
flame atomic adsorption spectroscopy (FAAS). Cadmium removal efficiency (R\%) for each substrate was calculated according to the following equation (Equation (8)):

$$
R \%=\frac{C_{o}-C_{f}}{C_{o}} \times 100
$$

where $C_{o}$ is the initial concentration of the $C d$ ion in the stock solution $(\mathrm{mg} / \mathrm{L})$; and $C_{f}$ is final concentration of the $\mathrm{Cd}$ ion in the treated solution $(\mathrm{mg} / \mathrm{L})$.

The amount of $\mathrm{Cd}$ ions removed on the substrates was calculated as (Equation (9)):

$$
q=\frac{C_{o}-C_{f}}{w} \times V
$$

where $q$ is the adsorption capacity $(\mathrm{mg} / \mathrm{g}) ; w$ is the substrate dosage $(\mathrm{g})$; and $V$ is the total Cd solution volume $(\mathrm{L})$.

Substrate Recovery

All the modified surfaces were weighted before and after the removal experiments. The percentage of mass recovered of each adsorbent after the removal experiments was calculated by the following relationship (Equation (10)):

$$
W R \%=\frac{W_{f}}{W_{o}} \times 100
$$

where $W R \%$ is the percentage of mass recovered; $W_{o}$ is the initial substrate dosage; and $W_{f}$ is the mass of filtered substrate from solutions after the removal experiments.

\subsection{Impact of Substrate Type and Surface Modifications}

The impact of the type of substrate and surface modification was investigated via adsorption experiments of $\mathrm{Cd}$ solution at a $0.1 \mathrm{mg} / \mathrm{L}$ concentration. The $\mathrm{pH}$ of the solutions was adjusted to 5.0 and the temperature maintained at room level $\left(18^{\circ} \mathrm{C}\right)$. The concentration of the remaining $\mathrm{Cd}$ ions was measured by FAAS after the substrates were filtered out with a $0.45 \mu \mathrm{m}$ PTFE filter.

\subsection{Effect of Solution $p H$}

The adsorbents exhibiting the highest removal efficiencies ( $\mathrm{R} \%$ ) were selected to investigate further the impact of $\mathrm{pH}$ on adsorption. In this regard, adsorption experiments were conducted at $\mathrm{pH}$ values ranging from 2.0 to 6.0 adjusted by adding either $0.1 \mathrm{M} \mathrm{HCl}$ or $0.1 \mathrm{M} \mathrm{NaOH}$ solutions. The initial Cd concentration for these studies was $0.1 \mathrm{mg} / \mathrm{L}$.

\subsection{Kinetic Studies}

In these experiments, silanized $\mathrm{Fe}_{3} \mathrm{O}_{4} \mathrm{NPs}\left(\mathrm{Fe}_{3} \mathrm{O}_{4} \mathrm{NPs} @ \mathrm{APTES}\right)$ at four different concentrations ranging from 0.0125 to $0.1 \%(w / v)$ were employed for removal experiments as described above. After the experiments, the adsorbents were recovered as explained above and the collected supernatants measured for cadmium contents as a function of time for up to $2 \mathrm{~h}$.

\subsection{Reusability Studies}

The reusability of the $\mathrm{Fe}_{3} \mathrm{O}_{4}$ NPs@APTES was analyzed by carrying out four full operation cycles of $0.1 \mathrm{mg} / \mathrm{L} \mathrm{Cd}$ removal at $\mathrm{pH}$ 4.0. After each cycle, the material was removed from the solution, transferred to a fresh $\mathrm{Cd}$ solution, and maintained therein overnight. Cd removal was measured with respect to the control solution before and after exposure for a period of 5 days.

Desorption studies were performed to investigate the feasibility for regeneration and reusability of the substrates. The $\mathrm{Cd}$ removal assays for $\mathrm{Fe}_{3} \mathrm{O}_{4} \mathrm{NPs} @ A P T E S$ started at $\mathrm{pH}$ 5.0 and at a $\mathrm{Cd}$ concentration of $0.1 \mathrm{mg} / \mathrm{L}$. Then, adsorbents were separated, recovered, and 
placed independently for $1 \mathrm{~h}$ in a $0.1 \%(v / v) \mathrm{HCl}$ solution followed by rinsing multiple times with milli-Q water to desorb Cd ions from their surfaces. The regenerated adsorbents were added later on to fresh $\mathrm{Cd}$ solutions under the same conditions to compare their removal efficiencies with those of pristine materials. The desorption efficiency was calculated using the following equation (Equation (11)) [18]:

$$
\text { Desorption efficiency }(\%)=\frac{C_{d e}}{C_{a}} \times 100
$$

where $C_{a}(\mathrm{mg} / \mathrm{L})$ is the concentration of the originally adsorbed Cd ions, and $C_{d e}(\mathrm{mg} / \mathrm{L})$ is the concentration of $\mathrm{Cd}$ in the solution after the desorption process.

\subsection{Potential Environmental Impact}

Different toxicity tests were conducted for the adsorbents with the highest $\mathrm{Cd}$ removal efficiencies to assess their potential environmental impact before their discharge to superficial waters.

\subsubsection{NPs Phytotoxicity}

$\mathrm{Fe}_{3} \mathrm{O}_{4}$ NPs phytotoxicity was determined by measuring the germination and stem length of Lolium perenne seeds (Ryegrass) (Agrosemillas, Medellin, Colombia) placed on a filter paper in culture plates. Solutions with unmodified NPs and modified with APTES, APTES@Cys and CAS at six different concentrations $(0.01,0.1,1,10,100,1000 \mu \mathrm{g} / \mathrm{mL})$ in water were added to the culture plates with 6 seeds per well. Seeds were grown for seven days under static conditions at $18^{\circ} \mathrm{C}$ and light cycles of $10 \mathrm{~h}$.

\subsubsection{NPs Toxicity in Zebrafish Embryos}

Adult, TAB wild type, zebrafish were maintained under a constant $14 \mathrm{~h}$ light- $10 \mathrm{~h}$ dark cycle at $28^{\circ} \mathrm{C}$, according to standard protocols [60] in a controlled multitank recirculating system (Aquaneering, San Diego, CA, USA). The day before eggs were required for the assay, adults were placed in breeding tanks and allowed to breed. Embryos were collected $1 \mathrm{~h}$ after light was turned on the next morning and raised on 6-well microplates in egg water $\left(60 \mu \mathrm{g} / \mathrm{mL}\right.$ sea salt in $\mathrm{RO}$ water with $1 \mathrm{mg} / \mathrm{L}$ Methylene Blue) at $28^{\circ} \mathrm{C}$ until $3 \mathrm{~h}$ post fertilization (dpf).

Groups of 10 embryos (3hpf) were exposed to $\mathrm{Fe}_{3} \mathrm{O}_{4}$ NPs @APTES at different concentrations $(25,50,100 \mathrm{mg} / \mathrm{L})$ until $4 \mathrm{dpf}$. Egg water was used as negative control. Each treatment was performed in triplicate, under the same conditions, and every $24 \mathrm{~h}$, the water with the treatment was changed according to the protocols indicated by the OECD guide [56].

Survival of the embryos was determined by observations of movement, heartbeat, and blood circulation aided by a stereoscope microscope AZ100M (Nikon, Tokyo, Japan) at 3, 24, 48, 72, and $96 \mathrm{~h}$. Embryos that appeared opaque and exhibited white color were considered coagulated and were removed from the tank. All protocols were approved by the Institutional Animal Care and Use Committee of Universidad de los Andes (CICUAL) with the C.FUA_19-004.

\subsubsection{Statistical Analysis}

Germination of seeds, root and shoot elongation data were analyzed via a two-way ANOVA (with NP type and concentration as factors) followed by a Bonferroni post hoc test and were expressed as the mean \pm standard deviation (S.D.).

Survival rate was determined during acute toxicity test (4 days) and was tested for $\mathrm{Fe}_{3} \mathrm{O}_{4}$ NPs @APTES, together with negative control (egg water). The collected data were analyzed with one-way ANOVA followed by Tukey test and were expressed as the mean \pm S.D. The statistical analyses were developed in Minitab 19 Statistical Software, and for all comparisons, the level of significance was established as $p \leq 0.05$. 


\section{Conclusions}

Due to the increasing amounts of cadmium and other heavy metals being released into the environment on a daily basis, more efficient and inexpensive routes for their capture are urgently needed. One interesting strategy to address this need is to develop potent adsorbents capable of capturing significant amounts of heavy metal ions, and with the potential of being reused several times. Here, we explored the use of bare and functionalized $\mathrm{Fe}_{3} \mathrm{O}_{4} \mathrm{NPs}$ and $\mathrm{Al}_{2} \mathrm{O}_{3}$ spheres as potential cadmium adsorbents. The already remarkable capacity of $\mathrm{Fe}_{3} \mathrm{O}_{4}$ for $\mathrm{Cd}$ adsorption was improved in more than $20 \%$ by surface functionalization with the organo-silane APTES. This was attributed to the significant increase in surface reactivity given by the pendant amine groups of APTES. For $\mathrm{Fe}_{3} \mathrm{O}_{4}$ NPs, an optimum $\mathrm{pH}$ of 5.0 was found for $\mathrm{Cd}$ removal, which was attributed to suitable charges for strong electrostatic interactions between $\mathrm{Cd}$ ions in the solution and the surface functional groups. Kinetic studies of cadmium adsorption suggest that the process is most likely controlled by the available active sites on the surface of the materials as well as by the cadmium ion concentrations in solution. All adsorbents can be easily recovered from water solutions with efficiencies higher than $80 \%$; however, despite having a relatively lower cadmium capturing capacity, $\mathrm{Al}_{2} \mathrm{O}_{3}$ spheres showed the best results. $\mathrm{Fe}_{3} \mathrm{O}_{4}$ NPs @APTES recycled up to four uses with more than $50 \%$ of their removal efficiency. No evident phytotoxicity was found for either the bare or functionalized adsorbents for concentrations below $100 \mu \mathrm{g} / \mathrm{mL}$. $\mathrm{Fe}_{3} \mathrm{O}_{4}$ NPs @APTES evaluated here showed that toxicity is concentration dependent. Survival data suggests exposures to concentrations below $50 \mu \mathrm{g} / \mathrm{m}$ are not harmful; however, more detailed studies that includes the effect on hatching, malformation, changes in behavior and possible nanoparticle bioaccumulation, among others; are suggested as future work.

Overall, these results indicate that metal ion retention is highly dependent on the porosity of the surface and the adsorbent's particle size. Similar cadmium removal percentages were achieved with both $\mathrm{Fe}_{3} \mathrm{O}_{4}$ and $\mathrm{Al}_{2} \mathrm{O}_{3}$. Further studies at a larger scale are required to evaluate whether the adsorbents can be potentially introduced into niche markets locally and internationally.

Author Contributions: Conceptualization, A.L.C., J.F.O. and J.C.C.; methodology, A.L.C., J.F.O., J.C.C. and R.R.; validation, A.L.C., J.F.O. and R.R.; formal analysis, A.L.C., A.G. and J.F.O.; investigation, A.L.C.; resources, J.F.O., J.C.C. and V.A.; data curation, A.L.C. and J.F.O.; writing-original draft preparation, A.L.C. and A.G.; writing-review and editing, A.L.C., J.F.O. and J.C.C.; visualization, A.L.C.; supervision, J.F.O., J.C.C., R.R. and V.A.; project administration, A.L.C. and J.F.O. All authors have read and agreed to the published version of the manuscript.

Funding: This research received no external funding.

Institutional Review Board Statement: All protocols involving animals were approved by the Institutional Animal Care and Use Committee of Universidad de Los Andes (CICUAL) with the C.FUA_19-004.

Data Availability Statement: The data and contributions presented in the study are included in the article. Further inquiries can be directed to the corresponding author.

Acknowledgments: The authors would like to thank CasaLuker S.A. (Colombia) for providing some of the reagents for the substrate surface functionalization. The authors also thank the Clean Room laboratory of the Department of Electrical and Electronic Engineering, the Department of Chemistry and the neuroscience and circadian rhythms laboratory at the School of Medicine for access to their facilities. The support for SEM image acquisition by the Center of Microscopy at Universidad de los Andes is gratefully acknowledged.

Conflicts of Interest: The authors declare no conflict of interest.

Sample Availability: Samples of the compounds are not available from the authors. 


\section{References}

1. Chowdhury, S.; Mazumder, M.A.J.; Al-Attas, O.; Husain, T. Heavy metals in drinking water: Occurrences, implications, and future needs in developing countries. Sci. Total Environ. 2016, 569-570, 476-488. [CrossRef]

2. World Health Organization (WHO). Cadmium in Drinking-Water: Background Document for Development of WHO Guidelines for Drinking-Water Quality; World Health Organization: Geneva, Switzerland, 2011.

3. Poon, C.P.C. Removal of Cadmium from Wastewaters; Birkhäuser: Basel, Switzerland, 1986; pp. 46-55.

4. U.S. Environmental Protection Agency and Compliance Assurance. National Primary Drinking Water Regulations; U.S. Environmental Protection Agency and Compliance Assurance: Washington, DC, USA, 2013; pp. 141-142.

5. Godt, J.; Scheidig, F.; Grosse-Siestrup, C.; Esche, V.; Brandenburg, P.; Reich, A.; Groneberg, D.A. The toxicity of cadmium and resulting hazards for human health. J. Occup. Med. Toxicol. 2006, 1, 22. [CrossRef] [PubMed]

6. World Health Organization. Exposure to cadmium: A major public health concern. In Preventing Disease Through Healthy Environments; World Health Organization: Geneva, Switzerland, 2010; pp. 3-6.

7. Asthana, M.; Kumar, A.; Sharma, B.S. Wastewater Treatment. In Principles and Applications of Environmental Biotechnology for a Sustainable Future; Springer: Singapore, 2017; pp. 173-232.

8. Wang, Z.M. Nanotechnology for Water Treatment and Purification; Springer: Berlin/Heidelberg, Germany, 2014; Volume 22, ISBN 978-3-319-06577-9.

9. Jha, M.K.; Kumar, V.; Jeong, J.; Lee, J.C. Review on solvent extraction of cadmium from various solutions. Hydrometallurgy 2012, 111-112, 1-9. [CrossRef]

10. Lee, L.Y.; Morad, N.; Ismail, N.; Talebi, A.; Rafatullah, M. Optimization for liquid-liquid extraction of Cd(Ii) over Cu(ii) ions from aqueous solutions using ionic liquid aliquat 336 with tributyl phosphate. Int. J. Mol. Sci. 2020, 21, 6860. [CrossRef]

11. Li, B.; Peng, L.; Wei, D.; Lei, M.; Liu, B.; Lin, Y.; Li, Z.; Gu, J. Enhanced flocculation and sedimentation of trace cadmium from irrigation water using phosphoric fertilizer. Sci. Total Environ. 2017, 601-602, 485-492. [CrossRef]

12. Sulaymon, A.H.; Abdulmajeed, B.A.; Salman, A.B. Electrochemical removal of cadmium from simulated wastewater using a smooth rotating cylinder electrode. Desalin. Water Treat. 2015, 54, 2557-2563. [CrossRef]

13. Ounifi, I.; Ursino, C.; Santoro, S.; Chekir, J.; Hafiane, A.; Figoli, A.; Ferjani, E. Cellulose acetate nanofiltration membranes for cadmium remediation. J. Membr. Sci. Res. 2020, 6, 226-234. [CrossRef]

14. Mohan, D.; Singh, K.P. Single- and multi-component adsorption of cadmium and zinc using activated carbon derived from bagasse-An agricultural waste. Water Res. 2002, 36, 2304-2318. [CrossRef]

15. Hadavifar, M.; Bahramifar, N.; Younesi, H.; Rastakhiz, M.; Li, Q.; Yu, J.; Eftekhari, E. Removal of mercury(II) and cadmium(II) ions from synthetic wastewater by a newly synthesized amino and thiolated multi-walled carbon nanotubes. J. Taiwan Inst. Chem. Eng. 2016, 67, 397-405. [CrossRef]

16. Vuković, G.D.; Marinković, A.D.; Čolić, M.; Ristić, M.D.; Aleksić, R.; Perić-Grujić, A.A.; Uskoković, P.S. Removal of cadmium from aqueous solutions by oxidized and ethylenediamine-functionalized multi-walled carbon nanotubes. Chem. Eng. J. 2010, 157, 238-248. [CrossRef]

17. Gong, J.; Chen, L.; Zeng, G.; Long, F.; Deng, J.; Niu, Q.; He, X. Shellac-coated iron oxide nanoparticles for removal of cadmium(II) ions from aqueous solution. J. Environ. Sci. 2012, 24, 1165-1173. [CrossRef]

18. Kataria, N.; Garg, V.K. Green synthesis of Fe3O4 nanoparticles loaded sawdust carbon for cadmium (II) removal from water: Regeneration and mechanism. Chemosphere 2018, 208, 818-828. [CrossRef] [PubMed]

19. Wan, S.; Wu, J.; Zhou, S.; Wang, R.; Gao, B.; He, F. Enhanced lead and cadmium removal using biochar-supported hydrated manganese oxide (HMO) nanoparticles: Behavior and mechanism. Sci. Total Environ. 2018, 616-617, 1298-1306. [CrossRef]

20. Yang, J.; Hou, B.; Wang, J.; Tian, B.; Bi, J.; Wang, N.; Li, X.; Huang, X. Nanomaterials for the removal of heavy metals from wastewater. Nanomaterials 2019, 9, 424. [CrossRef]

21. Bhattacharya, A.K.; Venkobachar, C. Removal of Cadmium (II) by Low Cost Adsorbents. J. Environ. Eng. 1984, 110, 110-122. [CrossRef]

22. Saraeian, A.; Hadi, A.; Raji, F.; Ghassemi, A.; Johnson, M. Cadmium removal from aqueous solution by low-cost native and surface modified Sorghum $\times$ drummondii (Sudangrass). J. Environ. Chem. Eng. 2018, 6, 3322-3331. [CrossRef]

23. Jain, M.; Garg, V.K.; Garg, U.K.; Kadirvelu, K.; Sillanpää, M. Cadmium removal from wastewater using carbonaceous adsorbents prepared from sunflower waste. Int. J. Environ. Res. 2015, 9, 1079-1088. [CrossRef]

24. Boamah, P.O.; Huang, Y.; Hua, M.; Zhang, Q.; Liu, Y.; Onumah, J.; Wang, W.; Song, Y. Removal of cadmium from aqueous solution using low molecular weight chitosan derivative. Carbohydr. Polym. 2015, 122, 255-264. [CrossRef]

25. Jha, I.N.; Iyengar, L.; Rao, A.V.S.P. Removal of Cadmium Using Chitosan. J. Environ. Eng. 1988, 114, 962-974. [CrossRef]

26. Gupta, V.K.; Nayak, A. Cadmium removal and recovery from aqueous solutions by novel adsorbents prepared from orange peel and Fe2O3 nanoparticles. Chem. Eng. J. 2012, 180, 81-90. [CrossRef]

27. Panda, G.C.; Das, S.K.; Guha, A.K. Biosorption of cadmium and nickel by functionalized husk of Lathyrus sativus. Colloids Surf. B Biointerfaces 2008, 62, 173-179. [CrossRef] [PubMed]

28. Pyrzynska, K. Removal of cadmium from wastewaters with low-cost adsorbents. J. Environ. Chem. Eng. 2019, 7, 102795. [CrossRef] 
29. Hosain, A.N.A.; El Nemr, A.; El Sikaily, A.; Mahmoud, M.E.; Amira, M.F. Surface modifications of nanochitosan coated magnetic nanoparticles and their applications in $\mathrm{Pb}(\mathrm{II}), \mathrm{Cu}(\mathrm{II})$ and $\mathrm{Cd}(\mathrm{II})$ removal. J. Environ. Chem. Eng. 2020, 8, 104316. [CrossRef]

30. Chen, D.; Awut, T.; Liu, B.; Ma, Y.; Wang, T.; Nurulla, I. Functionalized magnetic $\mathrm{Fe}_{3} \mathrm{O}_{4}$ nanoparticles for removal of heavy metal ions from aqueous solutions. E-Polymers 2016, 16, 313-322. [CrossRef]

31. Mahdavi, S.; Jalali, M.; Afkhami, A. Heavy metals removal from aqueous solutions using tio2, $\mathrm{MgO}$, and $\mathrm{Al}_{2} \mathrm{O}_{3}$ nanoparticles. Chem. Eng. Commun. 2013, 200, 448-470. [CrossRef]

32. Koju, N.K.; Song, X.; Wang, Q.; Hu, Z.; Colombo, C. Cadmium removal from simulated groundwater using alumina nanoparticles: Behaviors and mechanisms. Environ. Pollut. 2018, 240, 255-266. [CrossRef]

33. Alotaibi, M.H.; El-Hiti, G.A.; Hashim, H.; Hameed, A.S.; Ahmed, D.S.; Yousif, E. SEM analysis of the tunable honeycomb structure of irradiated poly(vinyl chloride) films doped with polyphosphate. Heliyon 2018, 4, e01013. [CrossRef] [PubMed]

34. Surekha, K.; Sundararajan, S. Self-cleaning glass. In Anti-Abrasive Nanocoatings: Current and Future Applications; Elsevier Inc.: Amsterdam, The Netherlands, 2014; pp. 82-103. ISBN 9780857092175.

35. Clavijo, C.; Osma, J.F. Functionalized Leather: A Novel and Effective Hazardous Solid Waste Adsorbent for the Removal of the Diazo Dye Congo Red from Aqueous Solution. Water 2019, 11, 1906. [CrossRef]

36. Villa, S.; Riani, P.; Locardi, F.; Canepa, F. Functionalization of $\mathrm{Fe}_{3} \mathrm{O}_{4} \mathrm{NPs}$ by Silanization: Use of Amine (APTES) and Thiol (MPTMS) Silanes and Their Physical Characterization. Materials 2016, 9, 826. [CrossRef]

37. Perez, J.; Cifuentes, J.; Cuellar, M.; Suarez-Arnedo, A.; Cruz, J.C.; Muñoz-Camargo, C. Cell-penetrating and antibacterial BUF-II nanobioconjugates: Enhanced potency via immobilization on polyetheramine-modified magnetite nanoparticles. Int. J. Nanomed. 2019, 14, 8483-8497. [CrossRef] [PubMed]

38. Huang, S.W.; Lin, Y.F.; Li, Y.X.; Hu, C.C.; Chiu, T.C. Synthesis of fluorescent carbon dots as selective and sensitive probes for cupric ions and cell imaging. Molecules 2019, 24, 1785. [CrossRef] [PubMed]

39. Piri Fathabad, S.; Mosivand, S.; Kazeminezhad, I. Synthesis and Characterization of Electro-Crystallized Alumina Nanoparticles and Investigation of Their Application in Removal of Cobalt and Cadmium from Seimareh and Karoon Rivers in Iran. J. Electron. Mater. 2018, 47, 7034-7052. [CrossRef]

40. Wadie, A.; Al-Khawaja, E. Removal of cadmium Cd(II) and silver Ag(i) from aqueous solutions by nano activated alumina. Part I: Batch adsorption experiments. In MATEC Web of Conferences; EDP Sciences: Lez Ulis, France, 2018; Volume 162.

41. Meyer, J.; Ettlinger, M. Pyrogenically Prepared, Surface Modified Aluminum Oxide. U.S. Patent 7,442,727, 28 October 2008.

42. Garg, U.; Kaur, M.P.; Jawa, G.K.; Sud, D.; Garg, V.K. Removal of cadmium (II) from aqueous solutions by adsorption on agricultural waste biomass. J. Hazard. Mater. 2008, 154, 1149-1157. [CrossRef]

43. Ho, Y.S.; Chiu, W.T.; Wang, C.C. Regression analysis for the sorption isotherms of basic dyes on sugarcane dust. Bioresour. Technol. 2005, 96, 1285-1291. [CrossRef]

44. Sha, L.; Xueyi, G.; Ningchuan, F.; Qinghua, T. Adsorption of $\mathrm{Cu}^{2+}$ and $\mathrm{Cd}^{2+}$ from aqueous solution by mercapto-acetic acid modified orange peel. Colloids Surf. B Biointerfaces 2009, 73, 10-14. [CrossRef]

45. Vijayakumar, G.; Tamilarasan, R.; Dharmendirakumar, M. Adsorption, Kinetic, Equilibrium and Thermodynamic studies on the removal of basic dye Rhodamine-B from aqueous solution by the use of natural adsorbent perlite. J. Mater. Environ. Sci. 2011, 3, 157-170.

46. Javaheri, F.; Kheshti, Z.; Ghasemi, S.; Altaee, A. Enhancement of Cd2+ removal from aqueous solution by multifunctional mesoporous silica: Equilibrium isotherms and kinetics study. Sep. Purif. Technol. 2019, 224, 199-208. [CrossRef]

47. Boparai, H.K.; Joseph, M.; O'Carroll, D.M. Kinetics and thermodynamics of cadmium ion removal by adsorption onto nano zerovalent iron particles. J. Hazard. Mater. 2011, 186, 458-465. [CrossRef] [PubMed]

48. Lei, T.; Li, S.J.; Jiang, F.; Ren, Z.X.; Wang, L.L.; Yang, X.J.; Tang, L.H.; Wang, S.X. Adsorption of Cadmium Ions from an Aqueous Solution on a Highly Stable Dopamine-Modified Magnetic Nano-Adsorbent. Nanoscale Res. Lett. 2019, 14, 1-17. [CrossRef] [PubMed]

49. Azizian, S. Kinetic models of sorption: A theoretical analysis. J. Colloid Interface Sci. 2004, 276, 47-52. [CrossRef]

50. Guo, X.; Wang, J. A general kinetic model for adsorption: Theoretical analysis and modeling. J. Mol. Liq. 2019, 288. [CrossRef]

51. Kajjumba, G.W.; Emik, S.; Öngen, A.; Kurtulus Özcan, H.; Aydın, S. Modelling of Adsorption Kinetic Processes-Errors, Theory and Application. In Advanced Sorption Process Applications; IntechOpen: London, UK, 2019.

52. Kowanga, K.D.; Gatebe, E.; Mauti, G.O.; Mauti, E.M. Kinetic, sorption isotherms, pseudo-first-order model and pseudo-secondorder model studies of $\mathrm{Cu}(\mathrm{II})$ and $\mathrm{Pb}(\mathrm{II})$ using defatted Moringa oleifera seed powder. J. Phytopharm. 2016, 5, 71-78.

53. Lin, D.; Xing, B. Phytotoxicity of nanoparticles: Inhibition of seed germination and root growth. Environ. Pollut. 2007, 150, 243-250. [CrossRef] [PubMed]

54. Sun, Y.; Jing, R.; Zheng, F.; Zhang, S.; Jiao, W.; Wang, F. Evaluating phytotoxicity of bare and starch-stabilized zero-valent iron nanoparticles in mung bean. Chemosphere 2019, 236, 124336. [CrossRef] [PubMed]

55. Sun, G.; Liu, K. Developmental toxicity and cardiac effects of butyl benzyl phthalate in zebrafish embryos. Aquat. Toxicol. 2017, 192, 165-170. [CrossRef]

56. OECD. OECD Test No. 236: Fish Embryo Acute Toxicity (FET) Test. In OECD Guidelines for the Testing of Chemicals, Section 2; OECD Publications: Paris, France, 2013; pp. 1-22. [CrossRef] 
57. Almond, K.M.; Trombetta, L.D. The effects of copper pyrithione, an antifouling agent, on developing zebrafish embryos. Ecotoxicology 2016, 25, 389-398. [CrossRef] [PubMed]

58. Babayigit, A.; Duy Thanh, D.; Ethirajan, A.; Manca, J.; Muller, M.; Boyen, H.G.; Conings, B. Assessing the toxicity of Pb-and Sn-based perovskite solar cells in model organism Danio rerio. Sci. Rep. 2016, 6, 1-11. [CrossRef]

59. Haendel, M.A.; Tilton, F.; Bailey, G.S.; Tanguay, R.L. Developmental toxicity of the dithiocarbamate pesticide sodium metam in Zebrafish. Toxicol. Sci. 2004, 81,390-400. [CrossRef]

60. Westerfield, M. The Zebrafish Book. A Guide for the Laboratory Use of Zebrafish (Danio rerio), 5th ed.; University of Oregon: Eugene, OR, USA, 2007; ISBN 9994860577. 